\title{
Chapter 8 \\ Green BRI and 2030 Agenda \\ for Sustainable Development
}

\section{Aligning with Sustainable Development Goal 15 to Promote Global Biodiversity Conservation}

The Belt and Road Initiative (BRI) promises to create new opportunities for shared growth among countries through policy coordination, connectivity, unimpeded trade, financial integration, and people-to-people connections. It takes on new and deeper relevance amidst the global pandemic that has stricken the world. The fight against COVID-19 pandemic has made it abundantly clear that the global community is inescapably interconnected and needs stronger international collaboration through shared institutions and economic growth paths that are resilient, inclusive, and sustainable. The BRI has the potential to make major contributions to these needs.

The BRI has significant potential to boost the incomes of BRI countries and the world at large. According to the World Bank, the BRI could increase trade in BRI countries by $9.7 \%$ and foreign direct investment (FDI) by $7.6 \%$, which would lead to an increase in real income for Belt and Road economies by up to $3.4 \%$. Increases of standards of living in the BRI countries also benefit the rest of the world, which according to the World Bank would grow by up to an additional $2.9 \%$ due to the BRI. These estimates stand in sharp contrast with similar estimates for the Trans-Pacific Partnership, which would have boosted the growth of its membership by just $1.1 \%$ and the rest of the world by $0.4 \%$ [1].

Alongside the significant benefits associated with major infrastructure financing, large infrastructure finance is also endemic to a set of sustainability-related risks, including biodiversity risk, and the BRI is no exception. Some studies show that the BRI may become associated with losses in wildlife movement and mortality through habitat loss, the spread of invasive species, increases in illegal logging, poaching, and fires; and cause deforestation through the construction of roads, power lines and power plants, and subsequent mining activity. For these reasons, it is important to incorporate eco-environmental risk mitigation and management into the "green BRI" framework to align it with the 2030 Agenda for Sustainable Development. 
With the aim of fulfilling these commitments, this book examines how both China and the international community have learned over time to prevent and mitigate such risks. China's Ecological Red Line standards and analogous international practices offer a number of models that can be adapted to green the BRI with respect to biological diversity. The book includes further strategic principles for aligning the BRI with the Sustainable Development Goals (SDGs) and the Paris Agreement in general and establishing the green BRI Roadmap, which links three frameworks from the strategic aspect: the green BRI, the 2030 Agenda for Sustainable Development, and development goals of BRI participating countries. Specifically, this roadmap includes 4 major approaches. First, enhance policy communication. It is important to take the green BRI as an important practice of realizing SDGs and facilitating global environment governance reform with green development as the shared principle. Give full play to the role of BRI International Green Development Coalition (BRIGC) and other cooperation platforms. Second, enhance strategic alignment. It is suggested establishing the mechanism for linking Green BRI with the 2030 Agenda for Sustainable Development, actively promoting the alignment of environmental policies, planning, standards and technologies, and strengthening information sharing with the help of the BRI Environmental Big Data Platform. Third, improve project management. Establish and improve the mechanism for project management on green Belt and Road to further reinforce environmental management in BRI projects and prevent ecological and environmental risks from the development of BRI projects. Fourth, improve capacity building. It is recommended to jointly conduct green capacity building programs, such as the Green Silk Road Envoys Program, to create people-to-people bond in building green BRI.

Under the framework outlined by the above Roadmap for building a green BRI, with a special focus on Sustainable Development Goal 15 (SDG 15) and biodiversity conservation, more specific policy recommendations have been proposed to better align BRI, SDG 15, and CBD. This SPS recommends that China:

First, apply international norms and standards to facilitate the use of stricter environmental standards in BRI projects. It is recommended to actively align BRI efforts with the fulfillment of international and national commitments to international conventions, including the CBD and UNFCCC. Second, focus on environmental impacts and carry out assessment and classification-oriented management of BRI projects. It is recommended to boost the development of the guidance on assessment and classification of BRI projects, based on the on-going Joint Research on Green Development Guidance for BRI Projects undertaken by BRIGC, which could provide green solutions to BRI participating countries and projects. Third, improve policy instruments to prevent and control the eco-environmental risks related to BRI projects. It is recommended to carry out environmental impact assessment for key BRI sectors and projects and establish a regular environmental risk regulatory mechanism that incorporates environmental pollution, biodiversity conservation and climate change as important factors for assessment. It is important to make full use of green finance instruments and environmental risk assessment tools, and take ecological redlining as a key instrument. Fourth, improve the coordination mechanism 
and facilitate effective linkage and alignment among different SDGs using Nationbased Solutions (NBS). It is necessary to create synergies with efforts for SDG 13 of Climate Action.

\subsection{Linkages Between the Green Belt and Road and the 2030 Agenda for Sustainable Development}

\subsubsection{Background and Progress of Building the Green Belt and Road Initiative}

\subsubsection{The Background, Goal and Achievement of the Belt and Road Initiative}

Since the financial crisis in 2008, the world has recognized the need to forge new sources and patterns of economic growth. In this context, the Belt and Road Initiative (BRI) was proposed as China's contribution to a comprehensive solution for sustainable development. Pursuing the principles of extensive consultation, joint contribution and shared benefits, the BRI promises to create new opportunities for shared growth and prosperity among countries through policy coordination, connectivity, unimpeded trade, financial integration, and people-to-people connections. It takes on new and deeper relevance amidst the global pandemic that has stricken the world, as it has become acutely clear that major international efforts like the BRI can help bolster cooperation against pandemics and other international challenges like financial crises, climate change, and global biodiversity loss.

The accomplishments thus far have been impressive. From 2013 through 2019, cumulative commodity trade between China and countries along the Belt and Road, defined in the broadest terms, exceeded USD 7.8 trillion; direct investment to countries along the Belt and Road approximated USD 110 billion; and the value of new project contracts reached nearly USD 800 billion [2]. As estimated by the World Bank [3], implementing BRI projects will reduce the aggregate costs for trade among BRI participating economies by $3.5 \%$ and those for the trade between BRI participating economies with the rest of the world by $2.8 \%$. By November 2019 , the investment from Chinese enterprises in building economic and trade cooperation zones overseas in BRI countries amounted to USD 34 billion, creating tax revenue of over USD 3 billion and 320,000 local jobs [4]. According to the World Bank [3], the implementation of the Belt and Road Initiative has the potential to raise real income gains raise incomes in BRI countries by $3.4 \%$ and increase global real income by up to $2.9 \%$ for the rest of the world. The BRI has been recognized by the United Nations as a solution for facilitating the implementation of the 2030 Agenda for Sustainable Development. 
However, the BRI has even greater potential, specifically in the area of supporting biodiversity through high-quality infrastructure investment and global coordination. In April 2019, research findings and recommendation reports from the Advisory Council of the Belt and Road Forum (BRF) for International Cooperation (2019) highlighted that the Belt and Road Initiative and UN 2030 Agenda for Sustainable Development shared common ground in terms of facilitating cooperation, implementation instruments and measures, among others, which could achieve greater synergy.

\subsubsection{Progress of the Development of the Green BRI}

Since its inception, building the Belt and Road into a pathway for green development has been the aspiration and expectation of the Chinese government as well as the shared goal of all participating countries. China has accelerated its progress in building an ecological civilization, making unprecedented efforts in recent decades. The concepts of "putting ecological progress in the first place" and "green development" have been widely accepted by Chinese society as a consensus, and economic growth is shifting from a conventional model of "development first and green later" to high-quality development led by ecological civilization. By jointly building a green BRI with participant countries, China is creating a platform for countries to share and learn from one another the experience of green transitions and sustainable development. Over the past six years, China has been working closely with BRI participating countries in areas of environmental governance, biodiversity conservation and climate change mitigation and adaptation via bilateral and regional cooperation. It has witnessed positive and concrete results in building a green BRI and implementing the 2030 Agenda for Sustainable Development.

First, China has improved the BRI's top-level design and enhanced its cooperation mechanisms. In March 2015, the National Development and Reform Commission (NDRC), the Ministry of Foreign Affairs (MFA) and the Ministry of Commerce (MOFCOM) jointly issued their "Vision and Actions on Jointly Building Silk Road Economic Belt and 21st-Century Maritime Silk Road." The document proposes that China should promote ecological progress in conducting investment and trade, increase cooperation in ecological conservation, biodiversity protection, and climate change mitigation and adaptation. In 2017, the Ministry of Ecology and Environment (MEE, then Ministry of Environmental Protection) issued the "Belt and Road Ecological and Environmental Cooperation Plan" and launched the "Guidance on Promoting Green Belt and Road," which identified the roadmap for the development of a green BRI, together with the MFA, NDRC and MOFCOM.

As the BRI gradually unfolds, the green BRI framework is gaining a positive response from the international community. Currently, the MEE has signed nearly 50 bilateral and multilateral environmental cooperation agreements and has launched BRI International Green Development Coalition (BRIGC). The BRIGC was proposed by Chinese President Xi Jinping during the First Belt and Road Forum for International Cooperation (BRF), officially launched on the Thematic Forum 
of Green Silk Road of the Second BRF, and listed as one of the sectoral multilateral cooperation initiatives and platforms in the Joint Communique of the Leaders' Roundtable of the Second BRF. The main goal of BRIGC is to promote international consensus, understanding, cooperation and concerted actions to achieve green development of the BRI. To date, more than 150 Chinese and international organizations from over 40 countries have confirmed their partnership, including more than 70 overseas institutions such as government departments of BRI participating countries, international organizations, think tanks and businesses. Currently, BRIGC is actively promoting policy dialogues, thematic partnerships, and champion projects. The flagship research on BRI Green Development Report, the Joint Research on the "Green Development Guidance on BRI Projects" (the "Green Light" System), and the joint study on BRI Green Development Case Studies have been launched.

Second, platforms and modes for cooperation have been enriched to be more pragmatic. China has expanded platforms for collaboration, including the ChinaCambodia Environmental Cooperation Center and China-Laos Environmental Cooperation Office, which actively promote capacity building programs and champion projects. The Belt and Road Environmental Technology Exchange and Transfer Center (Shenzhen) was established to take advantage of the industrial resources of the area to promote innovative development and international transfer of environmental technologies. These platforms will facilitate environmental cooperation along the Belt and Road on regional and national levels. The BRI Environmental Big Data Platform (referred to as "the Big Data Platform") was officially launched. It has developed its own application (APP) for information updates, which helps to improve the "One-Map" system for integrated data services. With the help of information technologies, such as "Internet+" and big data, the Big Data Platform is designed to be an open platform for the exchange of ecological and environmental information through sharing and collaboration. It will provide environmental data support to BRI participating countries, including ecological environmental protection concepts, laws, regulations and standards, environmental policies and management measures, etc.

Third, China has promoted in-depth policy communication to build consensus on green development. China has made full use of existing international and regional cooperation mechanisms to share its vision, experience, and achievements in ecological civilization and green development, through the UN Environment Assembly, CEEC Ministers' Conference on Environmental Cooperation, and other international events. Meanwhile, the MEE is also engaged in opening up new channels for dialogue and communication. It held the Thematic Forum of Green Silk Road of the Second BRF for International Cooperation, organized sideline events on Green BRI during World Environment Day Celebrations, UN Climate Action Summit, and China-ASEAN Environmental Cooperation Forum, and sponsored more than 20 thematic forums each year on biodiversity conservation, climate change mitigation and adaptation, and eco-friendly cities with the attendance of more than 800 people from BRI participating countries and regions. 
Fourth, these cooperation projects have borne fruit. For example, the Chinese government has established the Green Silk Road Envoys Program to promote capacity building in environmental governance in China and BRI participating countries. This program has trained more than 2000 government officials, technological staff, youth, and scholars from 120 BRI participating countries. According to the List of Deliverables of the Second BRF, the Chinese government will continue to implement the Green Silk Road Envoys Program, which expects to train 1500 environmental officials from the BRI participating countries in the next three years. The Chinese government has also worked with relevant countries to jointly implement the Belt and Road South-South Cooperation Initiative on Climate Change to improve the capacity of BRI participating countries in addressing climate change and promote the implementation of the Paris Agreement. Moreover, China is also engaged in helping BRI participating countries in climate change mitigation and adaptation and energy transition, and promoting Chinese environmental technologies, standards, and low-carbon and energy-saving products in the international market through building low-carbon demonstration zones and organizing capacity building activities based on the reality and demands of BRI participating countries.

\subsubsection{The Focus on SDG 15}

In May 2019, the Intergovernmental Science-Policy Platform on Biodiversity and Ecosystem Services (IPBES) released the Global Assessment Report on Biodiversity and Ecosystem Services. The report evaluated the influence of biodiversity and ecosystem services on the economy, well-being, food security and life qualities. The report revealed that, over the past 50 years, the speed of biodiversity loss is unprecedented across human history. The top direct drivers for the most drastic biodiversity loss include changes in the use of land and sea, direct exploitation, climate change, and invasive alien species; while values and behaviors such as demographic and sociocultural changes, economic and technological factors, as well as institutions and governance are considered as critical indirect drivers for biodiversity loss. Overall, $75 \%$ of the terrestrial environment has been severely changed by human behavior and activities. The pressures brought by the above drivers made it difficult to attain the related goals set by the Convention on Biological Diversity (CBD) and the UN Framework Convention on Climate Change (UNFCCC), unless more revolutionary actions are taken. Similarly, to realize relevant goals and targets in the 2030 Agenda, revolutionary changes from the status quo protection speed and measures have to be implemented.

The year 2021 will mark an important turning point. The 15 th meeting of the Conference of the Parties (COP 15) to the CBD will take place in Kunming, China in 2021, with the theme of "Ecological Civilization: Building a Shared Future for All Life on Earth." COP 15 will review the Post-2020 Global Biodiversity Framework, set up 2030 objectives and targets for the conservation of global biodiversity, formulate 
the strategy for the conservation of global biodiversity in a new decade (2021-2030), and launch the new course of post-2020 global biodiversity conservation.

The 2030 Agenda has highlighted the significance of biodiversity, with SDG 14 "Conserve and sustainably use the oceans, seas and marine resources for sustainable development" to deal with marine biodiversity and SDG 15 "Protect, restore and promote sustainable use of terrestrial ecosystems, sustainably manage forests, combat desertification, and halt and reverse land degradation and halt biodiversity loss" to address issues with terrestrial biodiversity. In this sense, CBD COP 15 could be considered as a key window of opportunity to speed up the attainment of biodiversity-related SDGs.

Built on the results of the first phase of the Special Policy Study (SPS) on Green Belt and Road and 2030 Agenda for Sustainable Development, this SPS, as the second phase of the series, will take a goal-by-goal and step-by-step approach to the alignment of BRI and biodiversity-related SDGs. Given the severity of terrestrial ecosystem degradation and biodiversity loss, this SPS will primarily focus on SDG 15 as the entry point and propose policy recommendations for COP 15 on how to encourage BRI participating countries to better implement SDGs with the help of BRI.

\subsubsection{Progress of Countries Along the Belt and Road in Implementing SDG 15}

Progress is still lacking in achieving SDG 15 across BRI participating countries. The Sustainable Development Report 2019, published by the UN Sustainable Development Solutions Network (SDSN) and Bertelsmann Stiftung, evaluated progress among 193 countries in realizing SDG 13 (climate action), SDG 14 (life below water), and SDG 15 (life on land). It concludes that "trends on greenhouse gas emissions and, even more so, on threatened species are moving in the wrong direction."

The SDSN assesses the progress of $139+1$ countries along the Belt and Road towards realizing SDGs. The report selects five indicators to evaluate the implementation of SDG 15, including the mean area that is protected in terrestrial sites important to biodiversity (\%), the mean area that is protected in freshwater sites important to biodiversity (\%), the Red List Index of species survival, permanent deforestation ( 5 years average annual \%), and imported biodiversity threats (per million population).

SDSN finds particularly strong challenges in the geographic regions most closely associated with Belt and Road corridors: the Association of Southeast Asian Nations (ASEAN) as well as West and South Asian countries. These results are discussed below. The detailed evaluation results are shown in Fig. 8.1.

From the perspective of implementing SDG 15, SDSN finds that only four Central and Eastern European countries out of 140 countries have realized "Goal Achievement" of SDG 15: Poland, Hungary, Romania, and Bulgaria. The implementation of 


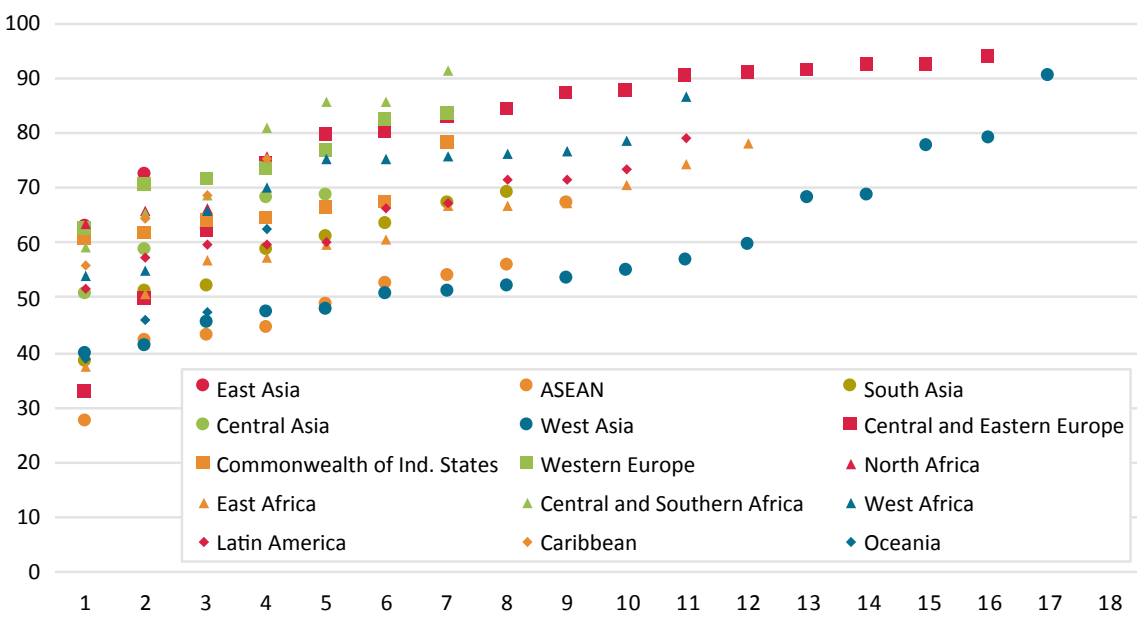

Fig. 8.1 Score of countries along the belt and road on SDG 15. Note Circles indicate Asia, squares indicate Europe, triangles indicate Africa, and diamonds indicate other regions

SDG 15 in Central and Eastern Europe is generally better than in other regions. For countries in other regions, there are various degrees of risks in the implementation of SDG 15. "Major Challenges" exist for three ASEAN Member States (Malaysia, Indonesia and Viet Nam), four in South and West Asia (Afghanistan, Iraq, Turkey, and Syria), four in East Africa (Djibouti, Madagascar, Seychelles, and Somalia) and four in Oceania (Fiji, Micronesia, the Solomon Islands, and Vanuatu).

Regarding the time sequence of implementing SDG 15, SDSN finds once again that Central Eastern European countries exhibit better performance than other regions. Ten out of 16 Central and Eastern European countries are on track or maintaining achievement, four countries show a moderately improving trend and two countries showed stagnation in their work. ASEAN Member States and countries in South Asia are the main areas facing challenges. The scores of SDG 15 in half of the 10 ASEAN Member States are decreasing, while two countries are in stagnation. Four countries out of eight in South Asia demonstrated a declining trend in implementation performance. Most countries in Central Asia and Commonwealth of Independence States (CIS) revealed stagnation in implementation, including five Central Asian countries and five out of seven CIS countries.

From the perspective of specific indicators, the most impactful indicator for ASEAN and South Asian countries in implementing SDG 15 is the Red List Index. Following a time sequence, the performance on this indicator in ASEAN and South Asian countries exhibited a decreasing trend. In addition, for ASEAN Member States, permanent deforestation also brings tremendous risks in implementing SDG 15. 


\subsubsection{Benefits and Biodiversity-Related Risks of BRI}

The BRI has the potential to close major infrastructure gaps, accelerate regional integration, and increase economic growth in a manner that advances progress towards the SDGs. Indeed, there is certain evidence that after just a few years the BRI is contributing to the achievement of some of these goals. Any large-scale development effort also has potential risks, and the key to the BRI's success will be to maximize the potential benefits while minimizing the potential risks. One such risk is the biodiversity decline that is often associated with major infrastructure investments in ecologically fragile areas with insufficient risk assessment in advance or risk management in operation. When accentuated, biodiversity loss can even jeopardize the economic returns of infrastructure investments.

Chinese President Xi Jinping exhibited China's commitment to biodiversity when he unveiled the Beijing Call for Biodiversity and Climate Change alongside French President Emmanuel Jean-Michel Frédéric Macron in late 2019. In the call, China and France pledge to lead by example to

Mobilize additional resources from all sources, both public and private, at the domestic and at the international level, towards both climate adaptation and mitigation; make finance flows consistent with pathways towards low greenhouse emissions and climate-resilient development, as well as for the conservation and sustainable use of biodiversity, the conservation of oceans, land degradation amongst others; ensure that international financing, particularly in the infrastructure field, is compatible with the Sustainable Development Goals (SDGs) and the Paris climate agreement. (China Daily, 2019, emphasis added)

This SPS is intended to conduct evidence-based research in order to formulate a framework of policies that will help the BRI be compatible with SDG 15. This section outlines the potential and realized benefits of the BRI and the potential biodiversity loss risks associated with the BRI.

\subsubsection{Benefits of the BRI}

The world community faces a financing gap of $2.1 \%$ of global GDP annually to 2030 in order to provide the infrastructure that is needed to meet the SDGs [5]. The China-led BRI has the potential to take a leading role in closing those gaps in a manner that is aligned with the SDGs. According to estimates from the World Bank [3], the transport corridors of the BRI will significantly increase economic growth in BRI countries. New transport corridors can increase the speed and efficiency of trade routes, connect isolated human settlements, and create better access to markets by facilitating the transportation of goods, services, and people across the world. When infrastructure is completed, there are boundless possibilities for "spillover effects" where new forms of economic activity arise that would not have without the infrastructure investment [6]. 
The BRI has significant potential to boost the incomes of BRI countries and the world at large. According to the World Bank, the BRI could increase trade in BRI countries by $9.7 \%$ and foreign direct investment (FDI) by $7.6 \%$, which would lead to an increase in real income for Belt and Road economies by up to $3.4 \%$ and by up to an additional $2.9 \%$ for other countries. In contrast, estimates for the Trans-Pacific Partnership (TPP) show that TPP would have boosted the growth of its membership by just $1.1 \%$ and the rest of the world by $0.4 \%$ [1]. The BRI then may have the largest potential to boost economic prosperity among participant countries and across the world.

These benefits are already being realized. Dreher et al. [7] looked at the impact of China's overseas projects financed by the China Development Bank, Export-Import Bank of China, and other Chinese financial institutions on economic growth in 138 countries. The authors found that on average a Chinese-financed project yields a $0.7 \%$ increase in economic growth two years after the project is committed.

\subsubsection{Biodiversity Risks and the BRI}

Alongside the significant benefits associated with major infrastructure financing, large infrastructure finance is endemic to a set of sustainability-related risks, including biodiversity risk, and the BRI is no exception. A handful of studies have already identified some of the potential biodiversity risks of the BRI. In a recent article in Conservation Biology, Hughes [8] spatially located proposed road and rail projects of the BRI (defined as those along the BRI corridors) and examined the extent to which such projects will be proximate to Key Biological Diversity Areas (KBAs) across the world. The author estimates that $16 \%$ of the world's KBAs are within $50 \mathrm{~km}$ of BRI proposed road projects and $60.6 \%$ of the world's KBAs lie within the BRI's proposed rail routes. The author also found that, $0.2 \%$ and $14.9 \%$ of KBAs are just $1 \mathrm{~km}$ from BRI road and rail routes respectively. In all, the author predicts that the BRI could endanger 4138 animal and 7371 plant species along the BRI [8]. A study published in Current Biology led by Xuan Liu [9] from the Chinese Academy of Sciences looks at the potential for the BRI to accentuate invasive species. They find that BRI countries fall in 27 of 35 recognized global biodiversity hotspots across the world and that the proportion of areas of high invasive species potential in BRI covered regions is 1.6 times larger than in non-BRI regions.

The earliest study was conducted by the World Wildlife Fund for Nature (WWF). According to WWF's analysis, BRI corridors in Eurasia overlap with the range of 265 threatened species including 39 critically endangered species and 81 endangered species, with 1739 Important Bird Areas or KBAs and 46 biodiversity hotspots or Global 200 Ecoregions. WWF finds the potentially most impacted areas to be 
the China-Indochina Peninsula Economic Corridor, the Bangladesh-China-IndiaMyanmar Corridor, and the China-Mongolia-Russia Economic Corridor. A background study for the World Bank analysis discussed above came to similar conclusions. The China-Indochina Peninsula Economic Corridor and China-MongoliaRussia Economic Corridor are facing the highest risks of biodiversity loss due to deforestation [10].

To appropriately address these risks, China's development finance institutions, which provide the bulk of the lending necessary for BRI projects to move forward, can institute safeguards that work with BRI signatory countries to screen, assess, and oversee the operation to ensure best practices. A 2020 study in Nature Sustainability evaluated policies in financiers associated with the BRI: 35 Chinese and 30 international institutions. The authors find that only 17 of these lenders require biodiversity impact mitigation, and only one of those is Chinese: the China-ASEAN Investment Cooperation Fund [11]. As a result, China faces potentially severe challenges in establishing cooperative mechanisms to oversee and mitigate biodiversity risks associated with specific BRI projects. This SPS explores lender safeguards and biodiversity risk mitigation in more detail below, in order to explore the potential for advancement in these areas.

Biodiversity loss also reduces economic well-being. A study published in the journal Global Environmental Change found that between 1997 and 2011, the world economy lost between USD 4 trillion and USD 20 trillion per year in ecosystem services from land cover changes [12]. A 2019 World Bank study examining the economic impact of conservation efforts in Kenya shows that biodiversity management can make the difference between infrastructure projects having positive or negative economic impacts, because of impacts on ecosystem services for surrounding communities [13].

Risks to biodiversity clearly carry potential impacts for human communities, but those impacts can manifest differently across gender lines, which can severely curtail the effectiveness of conservation planning if it is not taken into account. In many rural, poor settings, biodiversity loss impacts women to a greater extent than men, especially in communities where women are tasked with collecting water, firewood, and wild foods, which is common in developing countries globally [14, 15]. If forests and riverine ecosystems are damaged, their tasks become more onerous, requiring farther travel in often insecure areas.

If the BRI does not develop and institutionalize a strategic set of appropriate policies and standards to mitigate the biodiversity risks, it could encounter financial, social, environmental, and political risks as well that may further erode the maximum potential of the BRI. Fragile ecosystems can jeopardize the integrity of infrastructure projects, reduce financial rates of return, and accentuate debt-driven macroeconomic stress in host governments and on the balance sheets of Chinese financiers. Furthermore, increased degradation of biodiversity can lead to social conflict and reputational risks that can also threaten the geo-political relationships that are so important to the BRI as well. For these reasons and more it is important to control biodiversity risks associated with the BRI. 


\subsection{An Analysis of Relevant Policies and Standards on SDG 15}

\subsubsection{Research and Evaluation of China's Experience}

\subsubsection{Biodiversity Conservation in China}

China is among the world's megadiverse countries, yet its biodiversity is seriously threatened. To strengthen biodiversity conservation, China has been conducting biodiversity surveys, assessments of endangered categories of ecosystems and species and in-situ and ex-situ conservation, as well as developing policies and regulations on biodiversity conservation.

In terms of in-situ and ex-situ conservation, China has established a natural protected area system pivoting on national parks and also including nature reserves, scenic areas, forest parks, geographic parks, wetland parks, and cultural and natural heritage sites, among others. To supplement the natural protected areas, China has also established key ecological function zones and priority areas for biodiversity conservation. Currently, China has more than 10,000 protected areas, including national parks, nature reserves, forest parks, scenic areas, geographic parks, wetland parks, drinking water sources, and so on, covering $18 \%$ of the national land territory. At the same time, China has proposed an ecological function zoning scheme that consists of large-scale ecological function zones of different levels (including national key ecological function zones, important ecological function zones, biosensitive zones and vulnerable zones), which has played a significant role in protecting biodiversity and safeguarding national ecological security. However, even with these measures in place, China has still witnessed severe ecosystem degradation and accelerated biodiversity loss due to a lack of clear identification of natural protected areas' boundaries. The drawing of ecological redlines could identify areas with unique ecological functions, which must be strictly protected in order to realize centralized management of the eco-space.

\subsubsection{Practices of Ecological Redlining in China}

(1) The Drawing and Management of Ecological Redlines

In October 2011, the State Council of China released the "Opinions on Strengthening Major Environmental Protection Work" to put forward ecological redlining for the first time. The document articulates the drawing of ecological redlines in major ecological function areas, sensitive areas and vulnerable areas for permanent conservation. In February 2017, the General Office of the CPC Central Committee and the General Office of the State Council jointly issued and circulated "Opinions on Drawing and Strictly Following Ecological Redlines," which established the framework, basic principles and overall goal 
of delineating and observing the ecological redlines. The release of this document represented a new phase of accelerated development of the ecological redline system in China.

(2) The Development of Scientific Methodology for the Drawing of Ecological Redlines

Scientific assessment is necessary before drawing ecological redlines. The aim of this step is to identify the spatial distribution of areas with critical ecological functions (such as water conservation, biodiversity protection, and water and soil preservation) and areas sensitive or vulnerable to water loss and soil erosion, desertification and salinization. The next step is to conduct a spatial mapping analysis of the two categories of areas and draw a redline for ecological protection that encompasses all development-prohibited areas at national and provincial levels and other protected areas in need of strict protection.

The design of ecological redlines aims to bring almost all rare and endangered species in China and their habitats under protection, with due consideration to China's own reality. Ecological redlining doesn't equal identifying new protected areas, but rather, constructing and optimizing the systems for ecological protection with a more scientific, comprehensive and systematic approach. It could turn existing protected areas into an integrated ecological protection system that is easy to manage. It contains both established protected areas of all kinds and areas that lack protection.

(3) The Establishment of the System for Delineating and Observing Ecological Redlines

In drawing the ecological redlines, the national government develops technical guidelines for provincial governments to decide the areas to be covered autonomously. Based on the "Methods for the Management of Ecological Redlines" issued by the Central Government, provincial governments develop their own methods with reference to local reality with detailed regulations on environmental access, the sustainable utilization of resources, ecological conservation and restoration, compensation for ecological protection and assessment and evaluation. Governments of all levels should take the responsibility of managing and regulating the ecological redlines.

(4) Significant effects have been achieved

In January 2018, the State Council approved the redline drawing plans from 15 provinces (autonomous regions and municipalities), including Beijing, Tianjin, Hebei, provinces and municipalities in the Yangtze River Economic Belt, and Ningxia. All these plans have been promulgated and implemented. In October 2018, the MEE and the Ministry of Natural Resources of China organized review meetings, principally approving the plans of drawing ecological redlines in 16 other provinces (autonomous regions and municipalities). The areas and sites covered by ecological redlines should be specified and demarcated after surveys. Still, based on the drawing plan, the ecological redline areas nationwide account for one-third of the national territory. Major ecological land within the redline boundaries, including forests, grasslands, 
and wetlands, accounts for $55 \%$ of the major ecological land nationwide. The natural protected area system pivoting on national parks has covered more than $18 \%$ of China's national land territory, surpassing the ratio of $17 \%$ set out by the 2020 Aichi Biodiversity Targets. The wild population of certain rare and endangered species such as the giant panda, crested ibis, and Tibetan antelope, has steadily increased. The major ecological land protected by the redlines covers the catchment areas of the Yangtze River, the Yellow River, and the Pearl River, among other major rivers at and above Category III in China, as well as all biodiversity-rich areas identified at the national level and the vast majority of biodiversity-rich areas defined at provincial levels. Redlining has also protected most river and lake water sources as well as some underground water sources, all the distribution areas of species on the List of Wildlife under Special State Protection, as well as the areas where protected fauna and flora are mostly distributed.

\subsubsection{The Experience of China in Biodiversity Conservation Through the Ecological Redline Policy (ERP)}

Ecological redlines help with biodiversity conservation through bringing areas with rich biodiversity and of importance under protection. In this way, habitats within the ecological redline can be preserved and restored, and in-situ and ex-situ biodiversity conservation can be realized.

(1) The drawing of ecological redlines should be scientific and rational

An integrated and systematic approach should be taken to drawing ecological redlines. Scientific assessment is needed for the identification of different areas based on the importance of ecological functions and the sensitivity and vulnerability of eco-environment. Areas within the ecological redline include all development prohibited areas on the national and provincial levels and other protected areas where strict protection is necessary.

(2) Human activities should be strictly controlled in areas protected by ecological redlines

In terms of functional positioning, ecological redlines are of great significance to maintaining ecological equilibrium and supporting sustainable economic and social development. Areas within ecological redlines are land with critical ecological functions, the use of which must be strictly controlled. In terms of conservation, ecological redlines represent the critical point and baseline for safeguarding ecological security. Areas within ecological redlines should never be allowed to see degradation in their function, shrinking in their size or change in their nature. In principle, ecological redlines should be managed the same way as "development prohibited" areas, with all development activities not in line with the function positioning of the areas being strictly prohibited.

1) The management of protected areas, including national parks, nature reserves, scenic areas, forest parks, geographic parks, world natural 
heritage sites, wetland parks, and drinking water sources, should follow related laws and regulations.

2) For other areas within ecological redlines, the following human activities are prohibited: mining activities; land reclamation, sand quarrying and other activities that may destroy coastlines; large scale agricultural activities, including wasteland reclamation, animal husbandry of scale and fishing; textile, printing and dyeing, leather manufacturing, paper-making and other manufacturing activities; real estate development; the construction of passenger and freight stations, ports and airports; coal-fired power and nuclear power generation and hazardous articles warehousing; the production of products with heavy pollution and high environmental risks listed in the Comprehensive Directory of Environmental Protection (2017), and production and operation activities with high environmental risks identified by Measures for the Administration of Compulsory Liability Insurance for Environmental Pollution.

(3) Ecological restoration and ecological compensation should be conducted in areas protected by ecological redlines

1) Conducting ecological restoration

China will soon develop plans for ecological conservation and restoration within ecological redlines that prioritize the protection of sound ecosystems and major habitats, restore damaged ecosystems, establish ecological corridors and sites, and improve the integrity and connectivity of ecosystems. Ecological restoration in areas protected by ecological redlines is identified as an important component in the protection and restoration of ecosystems, including mountains, waters, forests, lakes, and grasslands. The government is determined to effectively provide financial resources for ecological conservation and restoration by coordinating funding channels for various conversation and restoration projects within ecological redlines, such as programs on water and soil conservation, natural forest conservation, and comprehensive improvement of land and resources. Ecological restoration within marine ecological redlines will be conducted, based on the principle of integrated governance of the land and the sea, with special emphasis on the comprehensive management of estuaries, littoral zones, islands and polluted waters.

2) Introducing an ecological compensation mechanism integrating government funding and funding from other sources

Governments of all levels should increase their funding for areas protected by ecological redlines. Local governments are encouraged to launch fiscal, credit, financial, and tax policies to facilitate the implementation of ecological redline policies and establish ecological compensation mechanisms.

Local governments should develop diversified investment and financing mechanisms guided by the government with extensive public engagement to pool in resources from all sides. Governments are also encouraged to 
launch pilot programs on payment for ecosystem services and develop market-based mechanisms to realize the value of ecological products.

(4) Integrated monitoring should be developed and continuously improved for ecological redlines

It is important to access real-time statistics, improve the capability of the integrated analysis and application of monitoring data, be informed of the composition, distribution and dynamic change of ecosystems protected by ecological redlines, and keep track of human interference. Administrative decisions should be made in a scientific way with illegal acts being checked and handled in time.

(5) An accountability system should be established for safeguarding ecological redlines

1) Strengthening supervision for law enforcement

With the establishment of enforcement mechanisms for ecological redlining, regular supervision and inspection of law enforcement should be conducted to identify and punish illegal acts damaging ecological redlines. Should any violation appear, it should be investigated.

2) Establishing an assessment mechanism

Assessment of the performance of local governments in implementing ecological redlines should be conducted. The results of the assessment shall be a reference in determining the political achievements of local governments.

3) Strengthening the accountability system

Government officials whose decisions/actions cause severe damage to the ecological environment and resources shall be held accountable in all cases, regardless of their current positions.

4) Launching an incentive mechanism

Rewards should be given to organizations and individuals that have outstanding performance in protecting ecological redlines. It is recommended that personnel be assigned for the promotion of ecological redlines to improve the engagement of local residents.

5) Improving information transparency and public engagement

Governments should release information concerning ecological redlines, including their distribution and adjustment, to safeguard people's right to know, participate and supervise, and give full play to the role of the media, non-governmental organizations (NGOs) and volunteers in promoting ecological redlines. 


\subsubsection{Research and Evaluation from International Experience}

Adopting a set of harmonized standards for SDG 15 across the BRI can help minimize the risk and maximize the benefits and legitimacy of all actors involved, through bolstering environmental and social risk management (ESRM). This section reviews the international standards related to SDG 15 as practiced by the major multilateral financiers of infrastructure, integration, and development finance across the world, in two sections. First is a short note about the benefits of putting standards in place. Second is a comparative analysis of some of the major policies practiced by international actors.

Over the last few decades, environmental assessment and oversight systems have proliferated in the realm of international finance and investment. This section identifies the international actors that serve as peers for the Chinese financial institutions most active in BRI project finance and provides a survey of common practices among them. BRI projects predominantly receive financing through Chinese official entities such as the Silk Road Fund, the China Development Bank, and the Export-Import Bank of China, though not exclusively so [16]. Thus, the international equivalent for the sake of environmental governance of cross-border infrastructure development is the cohort of multilateral development finance institutions (DFIs) that have been traditional sources of support for BRI signatory countries.

\subsubsection{Benefits of Developing Green Standards and Safeguards Across the BRI}

Developing green standards can ensure that the BRI is calibrated to the SDGs while bringing benefits to virtually all of the stakeholders in the BRI. High-level or bestin-class environmental standards should thus take into account the preferences of Chinese and the other multitude of stakeholders engaged in the BRI to ensure that the BRI can provide public goods to the global economy as a whole (Table 8.1).

Standards can also increase project performance and profitability of projects. For example, in 2018 the International Finance Corporation (IFC) found that establishing standards across each of the common norms noted above were correlated with strong financial performance (measured by return on assets and return on equity) and financial risk ratings in 656 IFC projects representing USD 37 billion [19]. Risk instruments based on debt sustainability analysis (DSA) can help ensure that Chinese actors do not have to bear the risk of default on projects. While full assessments of the costs and benefits of ESRM are hard to quantify, the Independent Evaluation Group (IEG) of the World Bank (an independent monitoring group) conducted an assessment of the costs and benefits of ESRM in 2010 and concluded that benefits from the "environmental safeguards far outweigh the incremental costs" [17]. Weighing risks and benefits from a sample of bank projects, the World Bank found that most sensitive projects yielded "low cost-low benefits or high cost-high benefits for recipient 
Table 8.1 Benefits of standardizing the SDGs in the BRI

\begin{tabular}{|c|c|}
\hline \multicolumn{2}{|c|}{ Benefits of standards across the BRI } \\
\hline \multirow[t]{5}{*}{ Chinese actors } & Expansion of markets \\
\hline & Greater project effectiveness \\
\hline & Prevention from default risk \\
\hline & Prevention and mitigation of environmental and social risk \\
\hline & Prevention and mitigation of reputational risk \\
\hline \multirow[t]{5}{*}{ Host countries } & Improved management of fiscal resources \\
\hline & Better management of natural resources \\
\hline & Strengthening of institutional capacities \\
\hline & Prevention and mitigation of environmental and social risk \\
\hline & Prevention and management of reputational risk \\
\hline \multirow[t]{4}{*}{ Local communities } & Reduced likelihood of social conflict \\
\hline & Enhanced voice and ownership \\
\hline & Reduced vulnerability \\
\hline & Improved livelihoods \\
\hline \multirow[t]{4}{*}{ Global } & Equitable use of resources \\
\hline & Enhancement of global public goods \\
\hline & Interconnectivity and global growth \\
\hline & Leadership and legitimacy \\
\hline
\end{tabular}

Source Authors' adaptation base on World Bank [17], China Development Bank-UNDP [18]

countries." In the same IEG survey mentioned above, the World Bank also found that over half of the "task team leaders surveyed reported that the Bank's safeguards increased acceptability of the project among beneficiaries, and the safeguard policies also increased acceptability among nearly $30 \%$ of co-financiers" [17].

\section{Box 8.1. Case Study: Incorporating ESRM into Chinese Mining Enterprises in Peru}

Chinese financiers, firms, and the government can benefit substantially from establishing a set of harmonized standards around these common norms. First, these tools can help Chinese banks and firms expand and maintain market share overseas. China's experience in Peru is a case in point. Because of a lack of ESRM on the part of Chinese investors and the Peruvian government, China's first foray into Peru was a costly one. Chinese firms struggled to work with workers and local communities over worker health and safety, emergency preparedness, and biodiversity concerns. Though some of the issues were actually due to a lack of enforcement of host country systems rather than the Chinese firm, Chinese firms in general suffered reputational damage. Indeed, it became more difficult for Chinese firms to win contracts for mining and exploration 
in that country because of the perception that Chinese firms and financiers did not have proper risk management strategies. Later, Chinese copper firms devised significant ESRMs and participated in stakeholder consultations during the design stage. Such activity helped get market access and enhance China's reputation rather than worsen it. Indeed, when an accident did occur, ESRM plans allowed the company and host country to respond in such a way as to mitigate the worst damage $[20,21]$.

Standards can also benefit local communities close to projects. Engaging with local laborers and communities about a project beforehand can help identify concerns before they turn into conflicts. In Bolivia, Chinese tin companies took part in a prior informed consent engagement with local communities that rejected the location of the tin company. Bolivia found another community more suited and equipped for the project, likely deferring social conflicts that would have hurt the companies' business prospects and damaging China's reputation in general [21].

\section{Box 8.2. Beyond DFIs: Environmental Governance Systems in the United Nations}

Through United Nations mechanisms, nations have developed parallel systems to the systems of governance established by the DFIs profiled here. In this context, the CBD has long been a global platform for efforts to raise and harmonize national standards. CBD guidance is highly compatible with the "green BRI" framework, in that it encourages countries to collaborate in information sharing and capacity building to develop their own standards and practices (CBD 1992, Article 14).

In 2006, the CBD established voluntary guidelines for biodiversity-inclusive environmental impact assessment, including substantial upstream attention to identifying potential areas of concern. The guidelines encourage parties to focus upstream effort-before projects are proposed-in developing biodiversity mapping resources, such as the ones developed in China's recent history of demarcation of conservation priority areas. Individual project proposals can then be screened to ensure that all likely risks will be adequately addressed in the assessment stage. Impact assessments should be conducted with full participation by all stakeholders, to the extent possible. After individual projects' impact assessment, accountability mechanisms should be established to monitor and manage those projects' risks, and oversee any necessary mitigation [22]. CBD has also called for harmonization of standards among biodiversity financing mechanisms. Includes standards to apply in all cases, including but not limited to: highlighting and prioritizing the intrinsic value of biodiversity and its role in local livelihoods, effective public participation by project stakeholders, the establishment of institutional frameworks to oversee safeguard implementation. 
The Global Environment Facility (GEF) has been another important source of guidance on environmental standards. The GEF does not finance projects independently but rather works through co-financing. As such, its standards can "crowd in" other lenders and enable a broader reach. The GEF has nine minimum standards for projects, including assessment, accountability mechanisms, conservation practices, and restrictions on land use and the involuntary resettlement of existing communities. The first minimum standard, on environmental and social assessment, management, and monitoring, echoes CBD guidance in its requirement for project screening as early as possible to establish which risks - among those covered by this standard as well as the remaining eight-may apply to each project. The second standard requires the establishment of institutional mechanisms such as those described below, to address problems that may arise in an accountable and transparent fashion. While the scope of these safeguards represents a crucial element in the environmental management of international development finance, its scale is modest. GEF's current 4-year work cycle draws on $\$ 4.1$ billion in pledged funding [23]. That represents a tiny fraction of the development finance issued through major development finance institutions. For comparison, the World Bank has approved over $\$ 120$ billion in projects over the last four years [24]. For this reason, the international section of this paper focuses on the largest DFIs, which are the traditional sources of infrastructure finance in developing countries, as a comparison point for BRI projects.

\section{Box 8.3. Beyond DFIs: Environmental Governance Systems in the Private Sector}

In addition to the multilateral approaches profiled in this section, systems for private investment and finance have also made significant advances in recent years. Perhaps best-known are the Equator Principles, for use by private financial institutions in evaluating proposals for support. These begin with an emphasis on early review and categorization of projects, to ensure that project-level assessments adequately address all of the salient environmental and social risks, in a way that ensures the broadest possible public participation. They also include the importance of well-designed institutional accountability mechanisms, which work in conjunction with national judiciary remedies to ensure appropriate project management in practice [25]. Complementary to the Equator Principles are the International Organization of Standards' environmental management tools, collected under the title ISO-14000. These systems do not specify specific safeguards but cover the extent to which institutions have established their own standards, with a commitment to employee training and auditing to ensure compliance. 
While these frameworks can be important tools for private lenders and investors to better select and manage projects, they are not strictly analogous to projects financed under the BRI, which involve cooperation among national governments. Thus, this section focuses on common practices among development finance institutions, which have traditionally represented the bulk of infrastructure finance for developing countries.

\subsubsection{Comparative Analysis of Biodiversity Policy for International Financial Institutions}

This section of the report surveys the practices of eleven major international institutions financing infrastructure across the world with respect to biodiversity. What immediately emerges from such an analysis is a remarkable convergence with respect to the objectives and guiding principles across these institutions. Virtually all institutions seek to minimize the risks to biodiversity and aim to have "no net loss" or even a "net gain" in biodiversity. Moreover, most institutions also require biodiversity assessments tied to mitigation measures, and entail stakeholder engagement and consultation in the assessment and management of biodiversity. A detailed analysis of specific operations and policies also shows that there are major similarities across institutions as well.

The majority of the international financial institutions have established the goal of biodiversity as a core of their activities. The Asian Infrastructure Investment Bank (AIIB), the Development Bank of Latin America (CAF), as well as the World Bank (WB) and International Finance Corporation (IFC) all recognize the need to "integrate conservation needs and development priorities; through sustainable use of the multiple economic, social and cultural values of biodiversity and natural resources in an optimized manner." To measure and calibrate such goals, institutions range from a policy of "no net loss" of biodiversity (such as the AIIB) or alternatively "no net loss or a net gain in biodiversity" (such as the European Investment Bank, EIB, Asian Development Bank (ADB), German Development Bank, and the CAF).

The majority of the international financial institutions also converge significantly with respect to overarching principles and policy operations for biodiversity protection. Virtually all of the institutions require these five traits:

- Alignment with international commitments and national legal requirements;

- Exclusionary lists of categorically ineligible projects due to biodiversity.

- Requirements for biodiversity screening and impact assessments;

- Application of a subsequent "mitigation hierarchy" for no net loss or a net gain to biodiversity; and

- Meaningful stakeholder engagement and consultation in the assessment and management of biodiversity. 
Table 8.2 Operational requirements for biodiversity safeguards applied by DFIs

\begin{tabular}{|c|c|c|c|c|c|}
\hline \multicolumn{6}{|c|}{ International best practice for biodiversity conservation } \\
\hline & $\begin{array}{l}\text { Alignment with } \\
\text { international } \\
\text { and national } \\
\text { commitments }\end{array}$ & $\begin{array}{l}\text { Exclusionary } \\
\text { list of } \\
\text { categorically } \\
\text { ineligible } \\
\text { projects }\end{array}$ & $\begin{array}{l}\text { Biodiversity } \\
\text { impact } \\
\text { assessments }\end{array}$ & $\begin{array}{l}\text { Adopt } \\
\text { mitigation } \\
\text { hierarchy }\end{array}$ & $\begin{array}{l}\text { Stakeholder } \\
\text { engagement } \\
\text { and } \\
\text { consultation }\end{array}$ \\
\hline $\mathrm{ADB}$ & $\mathrm{X}$ & $\mathrm{X}$ & $\mathrm{X}$ & & $\mathrm{X}$ \\
\hline AfDB & $\mathrm{X}$ & $\mathrm{X}$ & $\mathrm{X}$ & $\mathrm{X}$ & $\mathrm{X}$ \\
\hline AIIB & $\mathrm{X}$ & $\mathrm{X}$ & $\mathrm{X}$ & $\mathrm{X}$ & $\mathrm{X}$ \\
\hline BNDES & $\mathrm{X}$ & & $\mathrm{X}$ & $\mathrm{X}$ & \\
\hline CAF & $\mathrm{X}$ & $\mathrm{X}$ & $\mathrm{X}$ & & $\mathrm{X}$ \\
\hline EBRD & $\mathrm{X}$ & $\mathrm{X}$ & $\mathrm{X}$ & $\mathrm{X}$ & $\mathrm{X}$ \\
\hline EIB & $\mathrm{X}$ & $\mathrm{X}$ & $\mathrm{X}$ & $\mathrm{X}$ & $\mathrm{X}$ \\
\hline IADB & $X$ & $X$ & $X$ & $X$ & $X$ \\
\hline IFC & $X$ & $X$ & $X$ & $X$ & $X$ \\
\hline KFW & $X$ & $X$ & $X$ & & $X$ \\
\hline WB & $X$ & $X$ & $X$ & $X$ & $X$ \\
\hline
\end{tabular}

Source Authors' analysis of official documents and interviews. Note ADB Asian Development Bank; AfDB African Development Bank; AIIB Asian Infrastructure Investment Bank; BNDES Brazilian Development Bank; $C A F$ Development Bank of Latin America; EBRD European Bank for Reconstruction and Development; $E I B$ European Investment Bank; IADB Inter-American Development Bank; IFC International Finance Corporation; $K f W$ German Development Bank; $W B$ World Bank

These policies are exhibited in Table 8.3. In Table 8.3, international institutions are listed vertically and specific biodiversity measures are listed horizontally across the table. It should be noted however that while these institutions have these policies, they are not always executed, which can thus lead to negative outcomes for projects, biodiversity, and communities alike [26] (Table 8.2).

Table 8.3 shows that there is a great deal of practice with respect to biodiversity across the largest international development finance institutions in the world economy. For the purposes of clarity, we identified five core areas of commonality listed above in the following: alignment with international commitments and national legal requirements; requirements for screening and assessments with specific biodiversity measures (and their related social impacts) that are fully disclosed; application of a subsequent "mitigation hierarchy" for no net loss or a net gain to biodiversity; entail stakeholder engagement and consultation in the assessment and management of biodiversity; and have an exclusionary list of categorically ineligible projects. This section of the paper highlights some of those programs.

(1) Alignment with international commitments and national legal requirements A common trait across all of the international institutions is to align the practices of the institution with specific global or national commitments and legal 


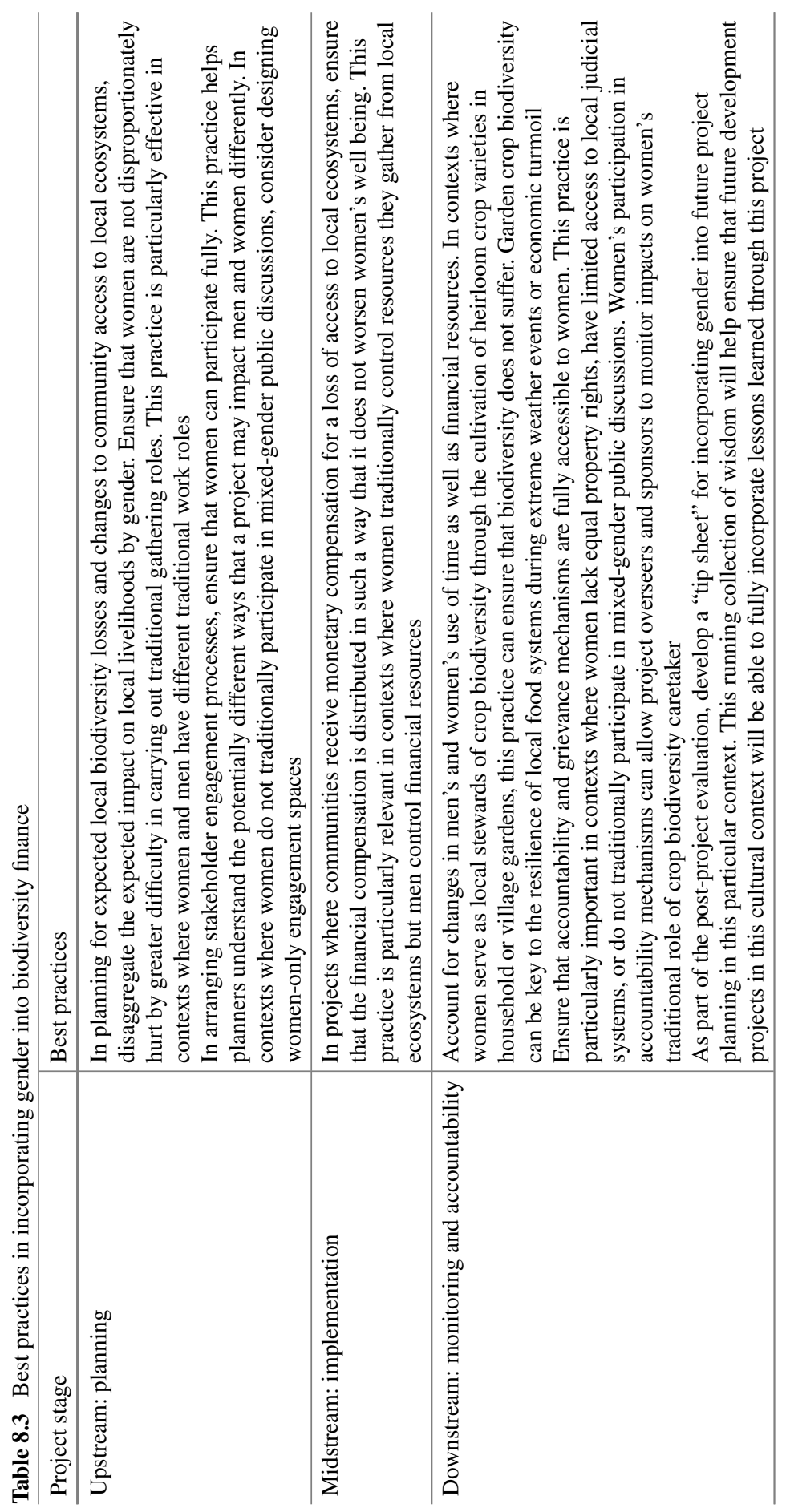


requirements. Most of the institutions surveyed have language such as the following from the AIIB: "The Bank will not knowingly finance Projects involving the following.... The production of, or trade in, any product or activity deemed illegal under national laws or regulations of the country in which the Project is located, or international conventions and agreements, or subject to international phase out or bans" [27]. The AIIB and others then provide an illustrative list of the kinds of international and national commitments they mean to adhere to (discussed below in "Exclusionary lists").

(2) Exclusionary lists of categorically ineligible projects due to biodiversity Often linked to the alignment language, the AIIB and others then provide an illustrative list of the kinds of international and national commitments they mean to adhere to. In the case of the AIIB they list the following [27]:

- "Trade in wildlife or production of, or trade in, wildlife products regulated under the Convention on International Trade in Endangered Species of Wild Fauna and Flora (CITES),"

- "Activities prohibited by legislation of the country in which the Project is located or by international conventions relating to the protection of biodiversity resources or cultural resources, such as, Bonn Convention, Ramsar Convention, World Heritage Convention and Convention on Biological Diversity."

- Commercial logging operations or the purchase of logging equipment for use in primary tropical moist forests or old-growth forests.

- "Production or trade in wood or other forestry products other than from sustainably managed forests."

- "Marine and coastal fishing practices, such as large-scale pelagic drift net fishing and fine mesh net fishing, harmful to vulnerable and protected species in large numbers and damaging to marine biodiversity and habitats."

Most of the international institutions in the survey extend the possibility of excluding a project beyond these international and national commitments to cases where screening and environmental impact assessments may warrant it. Most have similar language on this matter. The African Development Bank's policy reads that "If the Bank finds that the environmental or social impacts of any of its investments are not likely to be adequately addressed, the Bank may choose not to proceed with the investment.... When the habitat/biodiversity implications of a project would appear to be particularly severe, the Bank may decide not to finance the project" [28].

(3) Requirements for biodiversity screening and impact assessments

All of the major international institutions surveyed also perform analyses of biodiversity impacts as part of broader environmental impact assessments. With respect to biodiversity, these policies charge the institution to consider the direct, indirect and cumulative project-related impacts on the habitats and the biodiversity they support. The World Bank considers threats to biodiversity, for example habitat loss, degradation and fragmentation, invasive alien species, 
overexploitation, hydrological changes, nutrient loading, pollution and incidental take, as well as projected climate change impacts. The World Bank also determines the significance of biodiversity or habitats based on their vulnerability and irreplaceability at the global, regional or national levels and will also take into account the differing values attached to biodiversity and habitats by project-affected parties and other interested parties [29]. Similar or identical language is found in the policies of most of the institutions studied here (see Table 8.3).

The CAF is one institution with a slightly different language and scope. Its policy states that it will examine "Relevant physical, biological, and socioeconomic conditions within the study area, In particular, environmentrelated aspects likely to be significantly affected by the proposed development, including, in particular, population, fauna, flora, soil, water, air, climatic factors, material assets, including the architectural and archaeological heritage, landscape and the interrelationship between factors above. Current and proposed development activities within the project's area of influence, including those not directly connected to the project" [30].

The Inter-American Development Bank (IADB) operates in such biodiverse places such as the Amazon basin which is home to many nations. The IADB's policy also addresses transboundary biodiversity issues associated with a project. The environmental assessment process for the IADB seeks to identify, early in the project cycle, transboundary issues associated with the operation. The environmental assessment process for operations with potentially significant transboundary environmental and associated social impacts, such as operations affecting another country's use of waterways, watersheds, coastal marine resources, biological corridors, regional air sheds, and aquifers, will address the following issues: (i) notification to the affected country or countries of the critical transboundary impacts; (ii) implementation of an appropriate framework for consultation of affected parties; and (iii) appropriate environmental mitigation and/or monitoring measures, to the bank's satisfaction.

In addition to estimating biodiversity impacts, international bodies recommend that economic impacts be differentiated on a gender basis, in order to estimate the indirect impact on women's work as stewards of crop biodiversity. The CBD's 2015-2020 Gender Action Plan calls for calculating project costs and benefits should be estimated differently for women and men, rather than collectively, as do the Green Climate Fund and Climate Investment Funds [31-33].

(4) Adopting a mitigation hierarchy to address identified concerns

To the extent that the compulsory biodiversity impact assessments identify issues that may impact biodiversity, Table 8.3 shows that most of the major international financial institutions (eight of the 11 surveyed) require a "mitigation hierarchy" to meet the overall objective of "no net loss" or a "net gain" in biodiversity. The mitigation hierarchy has the following four pillars: 
- Avoidance: measures taken to avoid creating impacts from the outset, such as careful spatial or temporal placement of elements of infrastructure, in order to completely avoid impacts on certain components of biodiversity.

- Minimization: measures taken to reduce the duration, intensity and/or extent of impacts (including direct, indirect and cumulative impacts, as appropriate) that cannot be completely avoided, as far as is practically feasible.

- Rehabilitation/restoration: measures taken to rehabilitate degraded ecosystems or restore cleared ecosystems following exposure to impacts that cannot be completely avoided and/ or minimized.

- Compensation: measures, such as offsets, taken to compensate for any residual significant, adverse impacts that cannot be avoided, minimized and/or rehabilitated or restored, in order to achieve no net loss or a net gain of biodiversity. Offsets can take the form of positive management interventions such as restoration of degraded habitat, arrested degradation or averted risk, protecting areas where there is imminent or projected loss of biodiversity.

(5) Stakeholder engagement, consultation and disclosure:

All of the institutions surveyed for this SPS require stakeholder engagement and consultation in the assessment and management of biodiversity. Each of the institutions makes some commitment to carry out consultations with affected peoples and communities and seek their informed participation throughout the project cycle.

As noted earlier, the CAF is perhaps the most engaged in major infrastructure projects in areas where there are significant concerns about biodiversity in areas that inhabit large and often vulnerable populations. The CAF requires that consultations with project-affected groups be held early in the environmental impact assessment process and maintained throughout the project cycle. Throughout the project cycle important information is supposed to be disclosed in a timely manner to affected groups, civil society organizations, and other key stakeholders. The CAF also requires that "The potential impact of projects over forests and natural habitats, and the rights of access to and use of resources for the welfare of the communities shall be evaluated as a part to the Environmental and Social Assessment" [30], 64.

The IFC requires that borrowers go so far as implementing a Stakeholder Engagement Plan. Where applicable, the Stakeholder Engagement Plan will include differentiated measures to allow the effective participation of those identified as disadvantaged or vulnerable. When the stakeholder engagement process depends substantially on community representatives, the client is required to make every reasonable effort to verify that such persons do in fact represent the views of affected communities and that they can be relied upon to faithfully communicate the results of consultations to their constituents. When affected communities are subject to identified risks and adverse impacts from a project, the client will undertake a process of consultation in a manner that provides the affected communities with opportunities to express their views on project risks, impacts and mitigation measures, and allows the client to consider and respond to them [34]. 
Development finance institutions have learned the importance of ensuring that their stakeholder engagement plans incorporate the voices of women, particularly in cases where communities may be facing displacement. As mentioned in Sect. 8.1.4.2 above, in many rural, poor settings around the world women do not customarily take part in public discussions but do bear the brunt of biodiversity losses, which can curtail their ability to serve as stewards of crop biodiversity, further potential biodiversity losses, and limit the benefits of conservation projects. For example, an inter-bank working group with representatives from the AIIB, ADB, AfDB, EBRD, EIB, IADB, NDB and the World Bank recently published joint recommendations on meaningful stakeholder engagement, which encourage project planners to ensure that these processes are designed specifically to prioritize the participation of women and other disadvantaged groups, and if necessary, disaggregate stakeholder engagement processes by gender [35].

\subsection{Analysis of SDG 15 Related Investments Possibilities}

Working towards SDG 15 is no small task. Biodiversity is fragile and necessary for the lives and livelihoods of global communities, and if damaged, difficult or impossible to regenerate. To prioritize it among the ever-accelerating world of international finance and investment, the field of biodiversity finance has emerged.

The need is certainly present and pressing. At a 2015 workshop in Beijing, the Intergovernmental Science-Policy Platform on Biodiversity and Ecosystem Services (IPBES) concluded that "urgent and concerted action" was needed to avert ecosystem degradation globally, for the sake of 3.2 billion people currently impacted by degraded lands [36]. Economically, they estimate that the losses caused by this biodiversity degradation amount to $10 \%$ of global GDP. These same authors track successful ecosystem restoration across every region and continent of the globe.

Biodiversity conservation is, by definition, an act that prioritizes long-term wellbeing over short-term booms. It requires investing in the natural capital necessary to support future economic production and human health. It also requires investing in activities that will pay off in positive externalities distributed throughout a wide array of communities, which the investor will not be able to completely reap themselves. Thus, it needs external encouragement in order to flourish, in the form of an enabling policy environment, preferential financial arrangements, and impact investors motivated to fuel positive change not only for their own portfolios but for the communities where they operate.

\subsubsection{Survey and Assessment of the Chinese Experience}

The SDG 15 aims to protect, restore and promote the sustainable use of terrestrial ecosystems. In recent years, China has continuously increased its financial input 
in ecological compensation mechanisms, transfer payments to ecological function areas, grassland compensation, subsidies for returning farmlands to forests, subsidies for wetland protection and restoration, and other programs. In the meantime, China has continued improving the property right system of natural resources, exploring new ways of cooperation among governments, businesses and environmental organizations, promoting sustainable forest management, combating desertification, halting and reversing land degradation, and halting biodiversity loss. In 2018, China scored 62.7 on SDG 15 , up by $7 \%$ compared with 2017 , indicating that certain progress has been achieved in terms of terrestrial ecosystem protection.

The ecological compensation mechanism continues to improve [37]. The Chinese government attaches great importance to the development of the ecological compensation mechanism and launched policy documents such as Suggestions on Improving the Ecological Compensation Mechanism, Guidelines for Accelerating the Development of a Horizontal Ecological Compensation Mechanism for Upper and Lower Reaches of Rivers, Action Plan for the Establishment of a Market-Oriented, Diversified Ecological Compensation Mechanism, Guidelines for Establishing and Improving the Long-term Mechanism for Ecological Compensation and Conservation in the Yangtze River Economic Belt, and Plan for A Pilot Program of Establishing a Comprehensive Ecological Compensation Mechanism. These documents establish the framework of an ecological compensation mechanism with Chinese characteristics. China had a fiscal input of nearly RMB 200 billion yuan in ecological compensation in 2019. Meanwhile, both the central and local governments have been taking market-oriented approaches to expand the source of funding for improving the ecological compensation mechanism. For example, the water source areas of the middle route of the South-to-North Water Diversion Project established ecological compensation through pairing cooperation; Jinhua City and Pan'an City in Zhejiang Province took the lead to adopt off-site development as a means of compensation; the drainage areas of Xin' an River engaged the private sector in ecological compensation programs; Moutai Group plans to invest a total of RMB 500 million yuan in 10 years starting from 2014 in water environment compensation in the drainage areas of Chishui River; and China Three Gorges Corporation has been playing an active role in the protection of the Yangtze River while exploring for market-oriented approaches to improve the compensation mechanism.

Transfer payments to ecological function areas have been increasing. To guide local governments to intensify the efforts to protect the ecological environment, and improve the capacity of local governments in places with national key ecological function areas to provide basic public services, the central government established the transfer payment system for key national ecological function areas in 2018 to support the protection of these areas. By the end of 2019, the central government has made transfers amounting to RMB 524.2 billion yuan to key national ecological function areas, of which RMB 81.1 billion yuan was made in 2019, RMB 9 billion yuan more than in the previous year, registering an increase of $12.5 \%$. Meanwhile, China has kept expanding the coverage of key national ecological function areas to 819 counties. Once included in national ecological function areas, local governments will receive financial and policy support as long as they strictly implement the negative 
RMB 100 million yuan

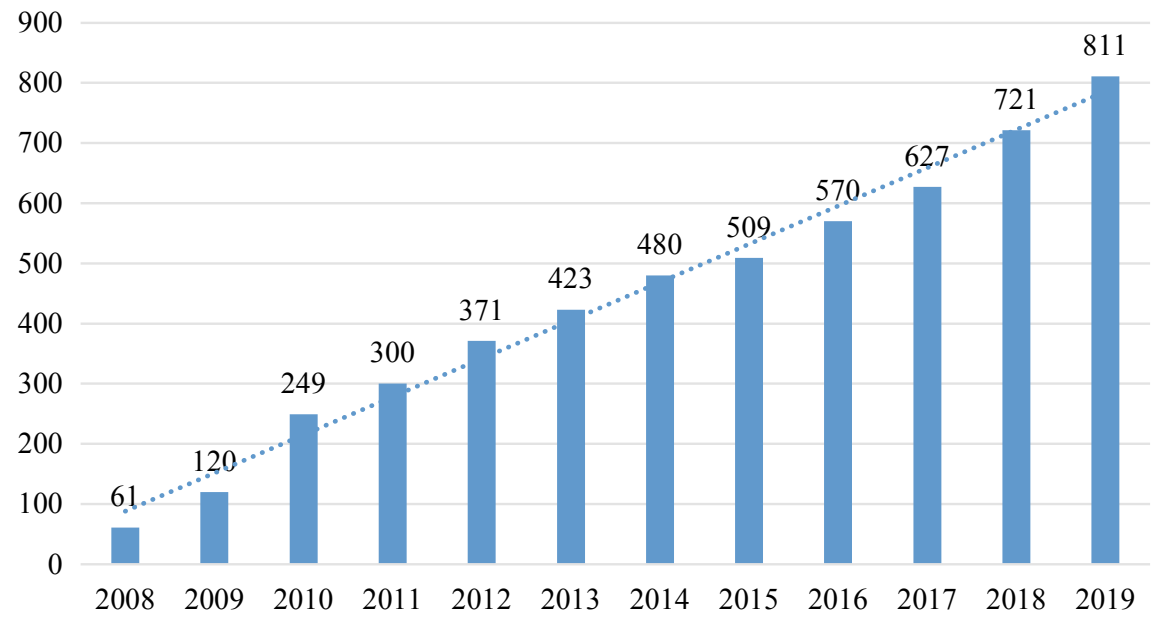

Fig. 8.2 Transfer payment to key national ecological function areas (2008-2018) [38] Source Dong et al, 39; Ministry of Finance, [40]

list system for industrial access. According to relevant regulations, a region counted as a key national ecological function area needs to strengthen ecological protection and restoration, regulate the boundaries of industrialization and urbanization, and enhance the supply capacity of eco-products (Fig. 8.2).

The standards for the compensation for ecological services of forests have been rising. In recent years, the central government has been increasing its input in compensation for ecological services of forests and raising the standards for compensation year by year. Starting from 2010, the standards of compensation for state-level non-commercial forests have varied according to their ownership. The compensation rate for state-owned state-level non-commercial forests was RMB 5 yuan/year $\mathrm{mu}(1 \mathrm{mu}=0.067 \mathrm{ha})$ in 2010 , while that of privately-owned and communityowned state-level non-commercial forests has increased from RMB 5 yuan/year mu to RMB 10 yuan/year mu. In 2013, the compensation rate for privately-owned and community-owned state-level non-commercial forests was raised to RMB 15 yuan/year mu. In 2015, 2016, and 2017, the rate for state-owned state-level noncommercial forests increased step by step, reaching RMB 6 yuan/year mu, RMB 8 yuan/year mu and RMB 10 yuan/year mu respectively. As the central government increases its fiscal input and raises the standards for compensation, local governments are expected to positively improve compensation system for ecological services of forests in local areas.

Policies for fiscal support to ecological protection and restoration of wetlands continue to improve. China attaches great importance to the protection of wetlands with increasing fiscal input in accelerating the development and optimization of policies concerning fiscal support to ecological protection and restoration. From 2013 to 
2016, the central government allocated RMB 5 billion yuan to protect wetlands in China and continued to provide support through the Funds for Reform and Development of Forestry afterwards. In 2014, the Ministry of Finance and the State Forestry Administration launched the pilot program of wetland ecological benefit compensation. For important wetlands on the route of migratory birds managed by the forestry system, their loss due to the protection of birds and other wild animals will be properly compensated. Currently, the central government allocates fiscal input to local governments, who will then decide the scope of wetland ecological benefit compensation and the areas to be protected.

\section{Box 8.4. Measures Taken by the Funds for Reform and Development of Forestry to Support Wetland Protection and Restoration}

The first measure entails supporting the protection and restoration of wetlands. For wetlands of international/national importance, national wetland parks at important ecological locations, and national wetland nature reserves at or above the provincial level managed by the forestry system, efforts will be made to protect and restore the wetlands, improve the current ecological status, and maintain the health of the local ecosystem.

The second measure entails supporting the restoration of farmland to wetland. It is encouraged to return farmlands to wetlands within the wetlands of international importance, national wetland nature reserves, and provincial nature reserves within wetlands of national importance managed by the forestry system, so as to expand the area of wetlands and improve the surrounding ecological status. The third measure entails supporting the wetland ecological benefit compensation. For important wetlands on the route of migratory birds managed by the forestry system, their loss due to the protection of birds and other wild animals will be properly compensated. In so doing, all parties are motivated to protect wetlands and maintain the wetlands' ecosystem service functions.

The grassland ecological protection subsidy incentive policy has been continuously promoted. To protect grassland ecosystem, guarantee the supply of meat and dairy products, and increase the income of herders, the Chinese government implemented the grassland ecological protection subsidy incentive policy. Currently, it covers eight major pastoral provinces (autonomous regions), including Inner Mongolia, Xinjiang, Tibet, Qinghai, Sichuan, Gansu, Ningxia and Yunnan, and five non-major pastoral provinces, such as Heilongjiang. RMB 152.033 billion yuan has been given as subsidies to 268 pastoral and farming-pastoral counties in the above provinces. In 2019, a new round of grassland ecological protection subsidy incentive of RMB 18.76 billion yuan was included in the central budget to support the banned grazing area of 1.206 billion mu and the grass-animal balance area of 2.605 billion mu (Fig. 8.3). 


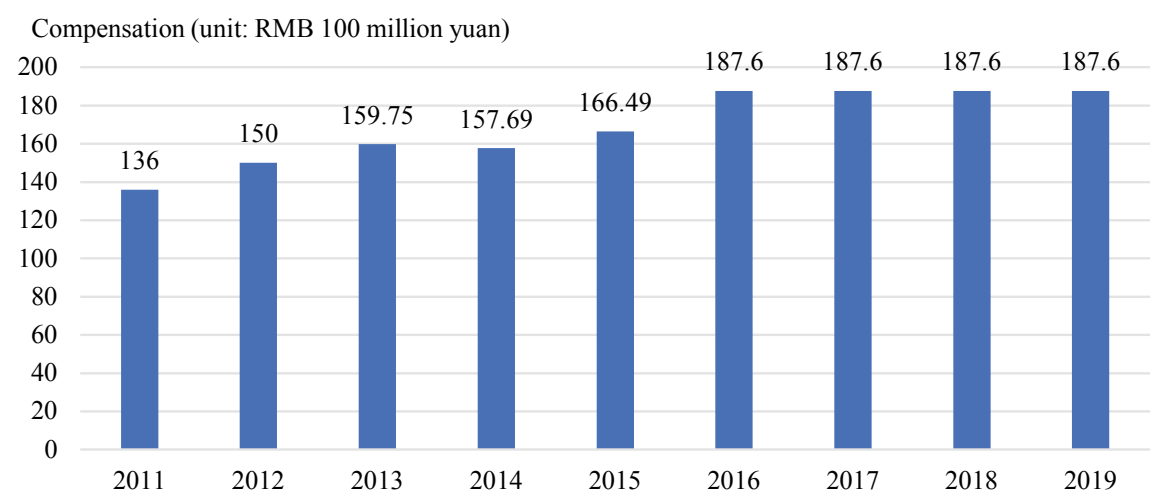

Fig. 8.3 Grassland ecological protection subsidy incentive (2011-2019). Source Chinese Academy of Environmental Planning [41]; Ministry of Finance website

The unified confirmation and registration of natural resources has been rolled out. The confirmation and registration of natural resources is important in promoting the reform of the property rights mechanism of natural resource assets, which is a key part of China's ecological civilization framework. By the end of October 2018, 1191 natural resource registration units have been established in 12 provinces (autonomous regions) and 32 pilot areas, and the total registered area has reached $186,727 \mathrm{~km}^{2}$. The state also focused on exploring the confirmation and registration of national parks, wetlands, water flows, and proven reserves of mineral resources. Starting from the end of 2018, the confirmation and registration of natural resources in key areas has been implemented nationwide step by step. It is planned that within 5 years, the unified confirmation and registration of natural resources in nature reserves will be completed, such as national and provincial key parks, natural reserves and various natural parks (scenic areas, wetland parks, natural heritage, geo-parks, etc.). At the same time, the unified confirmation and registration of individual natural resources with complete ecological functions owned by the public will be conducted, such as major rivers and lakes, key wetlands, key national forests, important grasslands, and other areas.

Innovative approaches have been taken to promote cooperation between governments, environmental organizations, and large enterprises. "Debt-fornature swaps" can be traced back to the 1980s. In a debt for nature swap, a nation agrees to swap the preservation of the natural environment for some of its debt. This benefits the nation because it brings its overall debt level down, and it benefits the environment by creating more protected habitat for animals and plants. Debt-fornature swaps may be organized by conservation organizations or by governmental organizations concerned with environmental preservation. Currently, China doesn't have any recorded cases of debt-for-nature swaps. However, there are many cases in which international organizations or large enterprises cooperate with governments in environmental protection for win-win benefits, mostly in the form of Payments for Ecosystem Services (PES). The project for the protection of water source jointly 
operated by The Nature Conservancy (TNC) and Longwu, Zhejiang Province is a case of such a practice. The project, with TNC as the consultant, protects water source areas with funding from trust agencies. The forest land is operated and managed in an integrated manner. The income from such operations is used to cover the compensation to farmers and the cost of the protection and management of the water source area. In this way, the water source could be properly protected and the trust fund company could get a fair share of economic return.

\section{Box 8.5. Water Source Protection Program Jointly Operated by TNC and Longwu, Zhejiang Province in the Form of Trust [42, 43]}

On January 15, 2015, TNC and the government of Huanghu County, Zhejiang Province, signed an agreement on the protection of Longwu Reservoir, a county-level water source. According to the agreement, the goal of the program is to reduce the factors that may cause water quality deterioration and improve the water quality of the reservoir from Class II to Class I. It is a good attempt to adopt a win-win model towards ecological conservation that could benefit both the environment and the community. Funded by Alibaba Foundation, it is the first water source protection program of TNC in China in the form of trust. In September 2015, Wanxiang Trust-TNC Charitable Trust decided to invest RMB 330,000 yuan to support the program [42] (Liu Liwen 2015).

In November 2015, Wanxiang Trust launched the first water fund trust in China-Wanxiang Trust-Shanshui Fund No. 1. Shanshui Fund Trust invited TNC to be the consultant. In the same month, the first water source protection and management project supported by the Trust-Longwu Small Water Source Protection Program was officially launched.

The program is an innovation that integrates social resources and engages multiple actors, including farmers, financial institutions, charity organizations, local organizations, businesses in the lower stream of the industrial chain related to agriculture in its daily operations. In this way, it could generate positive outcomes through interaction, collaboration and sharing. The program effectively addressed the issue of pollution caused by human activities that could benefit the whole community; it also established a sustainable funding mechanism that could bring environmental benefits and economic returns for investors.

Mode: Trust

Target of compensation: Residents in the nearby community

Main provider of compensation: Alibaba Foundation

Means of compensation: Farmers entrust the forest land to the trust and get steady income as compensation

Operation mechanism: The trust agency operates and manages the forest land while promoting the growing of bamboo shoot and ecological tourism. The income from such operations is used to cover the compensation to farmers and the cost of the protection and management of water source area. 


\subsubsection{Survey and Assessment of International Practices}

Globally, biodiversity finance has taken a variety of approaches, often in the form of PES or investments in soil and water health to ensure their ability to support future agriculture. The former category has been explored among developed as well as developing countries, under a variety of terms including "eco-compensation" in China and "agri-environmental programs" in the European Union [44]. A recent global survey in the journal Nature Sustainability estimates that over \$36 billion is invested in PES annually, with approximately one-third of that amount taking place within China [45]. Of the conservative USD 36 billion estimate, the great majority is estimated to be concentrated in watershed subsidies, which attract approximately USD 23.7 billion per year. One of the better-known examples of watershed PES programs among developing countries is found in Ecuador, where the capital city of Quito established the world's first municipal water fund, with the cooperation of TNC, in 2000 [46]. Quito's groundbreaking PES program (named FONAG for the Spanish acronym for Water Protection Fund) adds a surcharge on water users and included a bottled water plant in order to fund the conservation of the watershed that provides water for the municipality of Quito.

A second common approach-and one of particular importance for the context of a green BRI-is the use of biodiversity offsets. These financial arrangements seek to mitigate the net biodiversity impact (or create a positive net biodiversity impact if possible) due to new project construction by financing separate conservation efforts. Enabling policies for this type of biodiversity financing exist throughout Asia, Europe, and the Americas, but range widely in definition [47-49]. A recent study in Nature Sustainability which considered only those projects implemented under a "no net loss" policy, found nearly 13,000 such projects globally, cover an area of roughly $153,679 \mathrm{~km}^{2}$. Some of the largest existing such programs have occurred in very disparate countries, including: Mongolia, Brazil, and Uzbekistan [50]. However, as Gardner et al. [51] demonstrate in a Conservation Biology article, the "no net loss" standard is highly ambitious in practice, requiring comparable gains of new biodiversity (not simply conservation) relative to the biodiversity losses that are to be offset, and requiring that those gains be maintained over the long term. Accomplishing these goals requires strong institutional support and the involvement of a wide array of geographic locations, in order to effectively "hedge" the risks of partial project failure.

More broadly, biodiversity offsets take place within the mitigation hierarchy described in Sect. 8.2. As part of the "compensation" stage, offsets serve as a last option if the earlier options of avoiding, minimizing, and rehabilitating/restoring ecosystems and the communities that rely on them are not feasible or insufficient. For example, Villarroyo et al. [52] review the national policies regarding biodiversity offsets in Latin America and find that three countries' national regulations (Chile, Colombia, and Mexico) specifically make mention of both the mitigation hierarchy and offsets in relation to their EIA processes. However, many scholars note that significant institutional capacity building work remains in governments that seek to 
support offset schemes, particularly in establishing the scientific bases for "ecological equivalence" between geographic areas, in order to be assured of the net biodiversity impact of offset schemes [51-54].

Nonetheless, Luck et al. [55] find that global biodiversity finance has suffered from a severe geographical mismatch: flows have been directed mostly to low-priority ecosystems, while the most important ecosystems have been overlooked. Over half of all flows are focused on the United States, Canada, and Europe, despite the fact that these ecosystems are of "mutual low priority" for the two goals of preserving ecosystem services and biodiversity. Meanwhile, areas of high priority for both of those goals are concentrated in Southeast Asia and South America, which have attracted less than $15 \%$ of global biodiversity collectively. This mismatch is assuredly related to the fact that approximately half of all biodiversity finance stems from domestic government funding, and so funding is staying within wealthy countries. Thus, if the world is to make progress toward SDG 15, international biodiversity cooperation — through investment and especially aid—will be key.

\section{Incorporating Commercial Investors}

Traditionally, biodiversity finance has been limited to aid: official development aid (ODA) and philanthropy. However, opportunities for commercial investors have also been developing in recent years. Many types of biodiversity-maintaining or biodiversity-enhancing activities will pay for themselves in the medium-to-long term, though they require new sources of upfront financing to launch. By preserving or enhancing existing natural capital, these investment possibilities allow for reduced costs in economic production in the long term. For example, Burian et al. [56] advocate for agricultural investments aimed at building soil health and resilience, which will bring economic benefits in increased crop yields and decreased expenses on agrichemical inputs. IPBES estimates that the economic benefits of soil preservation are an average of 10 times greater than the cost of those efforts [36]. Finally, these benefits are multiplied as they impact downstream ecosystems through less-polluted waterways that better support both urban and rural life.

However, to succeed, biodiversity finance efforts must be well-matched with local needs, well-designed with local input, and well-managed by local governments. Clark et al. [57] find that the sector is beset by potential "greenwashing," in which commercial investors' activities are not actually biodiversity-enhancing or biodiversity-protecting, but market themselves as such in order to access advantageous financing and public reputational enhancements. While a few such investments may do no harm, allowing this type of activity to flourish under the banner of "biodiversity finance" brings risks to the entire sector, threatening the legitimacy of its claims and with it, its access to the favorable financing that will ensure its continued viability.

Bearing in mind the potential benefits as well as the potential risks, the United Nations Development Programme (UNDP)'s Biodiversity Finance Initiative (BIOFIN) has developed five areas of focus for developing frameworks for commercial biodiversity finance: 
- Policy and Institutional Review, examining the ways in which national institutions are sufficiency robust and well-designed to encourage biodiversity finance, as well as what areas can benefit from reforms (with the added optional aspect of identifying economic drivers of biodiversity loss);

- Expenditure Review, calculating current expenditures to support biodiversity;

- Needs Assessment, estimating the total amount necessary in biodiversitysupporting expenditures and the gap in actual spending;

- Finance Plan, setting targets and finding potential sources for this funding;

- Finance Solutions, establishing and carrying out a plan to address the institutional and financial gaps discovered in previous steps.

\section{Bilateral BIOFIN Cooperation Between Partner Governments}

As the sector of biodiversity finance continues to expand, and particularly as it opens to commercial activities, China has the opportunity to establish itself as a global leader in the field. The globally networked nature of the BRI highlights the importance of working to preserve biodiversity in the "hotspots" along the network, to ensure that the entire enterprise brings net benefits to the communities and the ecosystems that support them.

Two such "hotspots" stand out among potential partners for Chinese conservation finance, one on each side of the Pacific Ocean: Indonesia and Ecuador-two countries with BRI MOUs with China. Both are among the 17 mega-biodiverse countries, who collectively boast $17 \%$ of the world's species. They represent the peak of global terrestrial and marine biodiversity, respectively. Ecuador is home to the most biodiverse section of the Amazon rainforest, often called the "lungs of the earth" [58]. The Ecuadorian Amazon rainforest sits at the headwaters of the Amazon River, and ecosystem preservation there has the potential to benefit the downstream Amazon biome. Indonesia sits in the center of the world's marine biodiversity, sometimes called the "Amazon of the Seas" or the Coral Triangle, for the tremendous density and diversity of coral species there [59]. Both countries have made significant progress in their UNDP BIOFIN process, preparing to host and manage biodiversity finance successfully.

Furthermore, both Indonesia and Ecuador have strong economic ties with China. According to FDI Markets, China has created more new investment in Indonesia than in any other country in the last decade: over USD 52 billion. Ecuador, while a much smaller country, has also built up an important friendship with China. For the last decade, China has been Ecuador's most important creditor, creating deep goodwill between the two governments. In 2019, Ecuador became the first Latin American or Caribbean nation to become a full member of the AIIB, signaling its interest and institutional readiness to continue to strengthen its financial ties with Asia and in particular, with China.

One major obstacle to biodiversity preservation is a simple matter of geography: biodiversity hotspots are disproportionately located in developing countries, with limited fiscal space to design and carry out long-term projects that will not yield financial benefits for many years. One way to circumvent this problem is for these 
countries to collaborate in a bilateral or plurilateral fashion with their most important strategic partners, either creditor nations or major sources of investment, to ensure that the growth in economic activity between their nations does not bring environmental degradation. Three main models are common in the area of bilateral biodiversity finance: debt-for-nature swaps, National Environmental Funds (NEFs), and bilateral sustainable development banks.

In debt-for-nature swaps, creditors cancel a share of the debt in exchange for the debt service payments being redirected to maintain biodiversity. Alternatively, impact investors or international non-profit organizations play a pivotal role, negotiating a deal in which they buy a country's debt at a discount, work with the debtor nation to build the institutional infrastructure to oversee the biodiversity plan, and help establish a fund to support these activities. These deals can effectively cut off a vicious cycle of fiscal constraints leading to insufficient environmental management, hurting economic outcomes, reinforcing fiscal constraints.

When implemented well, debt-for-nature swaps can allow chronically indebted countries an alternative to environmentally-damaging activities to pay down debt. They can also create an institutional structure to oversee the establishment of definitions of sustainable economic activities appropriate for the newly protected areas, and the fiscal space to ensure that the new protections are well-managed, with adequate participation from local communities to ensure enforcement. However, debt-fornature swaps are not quick fixes for serious debt problems, nor can they bring a sudden stop to ongoing ecological disasters. As the case of Seychelles demonstrates, establishing the conservation areas is a process of multiple years. Thus, rather than being used as a last resort or rescue option for disaster scenarios, it is best considered as a long-term, proactive approach to conservation.

NEFs share many of the same characteristics of debt-for-nature swaps, but with less intervention on the part of outside partners. NEFs are locally-managed funds set up in collaboration with external partners, that support conservation efforts domestically. The "trust fund" nature of NEFs can make them particularly appropriate funding instruments for projects that need medium- or long-term investments, such as the delineation, establishment, and maintenance of national parks. For example, Brazil's Amazon Fund supports non-deforestation livelihood projects for forest-dwelling communities [60]. Other Amazon-basin countries including Bolivia, Colombia and Peru have NEFs to support their national systems of protected areas. In Asia, Bhutan and the Philippines both have similar funds [61].

While NEFs are managed by national governments, they can be established in conjunction with strategic partners overseas. For example, the Foundation for the Philippine Environment has been supported through debt swaps from the United States and Japan. In these cases, NEFs are similar to the debt-for-nature swaps profiled above, without the same level of detailed conditionality. Instead of debtor nations agreeing to set aside particular tracts of land, they establish general support for the nationally-defined conservation strategies. The fact that the local governments oversee the funds and their management makes them suitable for bilateral cooperation with partners that prefer to allow as much local direction as possible. 
Finally, bilateral conservation financing can take the form of special-purpose development banks. For example, the North American Development Bank is a project of the governments of the United States and Mexico, and was brought into being as part of the negotiations for the North American Free Trade Agreement (NAFTA), with the objective of ensuring that the U.S.-Mexico border would not be degraded due to the higher economic activity expected under NAFTA. It finances sustainable development projects on both sides of the border [62]. It has financed USD 1.2 billion in projects as of year-end 2018 [63]. This model may be particularly attractive in the establishment of cross-border transit corridors such as those in the BRI, or in partnerships between countries that expect to see significant increases in investment and trade.

\section{Box 8.6. Debt-for-Nature Swap in the Seychelles}

NatureVest, the biodiversity finance platform of TNC was founded in 2014 to mobilize private capital for conservation. In 2016, in conjunction with other private funders, NatureVest signed a deal with the Seychelles' Paris Club creditors, to buy a portion of Seychelles' debt at a discounted rate, spending approximately \$22 million for approximately \$25 million in debt.

In cooperation with the government of Seychelles, this debt relief will allow the establishment and maintenance of approximately $400,000 \mathrm{~km}^{2}$ of ocean. As of this writing, roughly half of that area has already been set aside, in the form of two new protected areas. The remainder is expected to be added within a year of this writing.

Two factors have contributed to the success of this debt-for-nature swap: the leadership of the government of Seychelles and the unhurried nature of the planning process. Through both of these strategies, this Seychelles project has been able to earn the local support necessary for management and enforcement over the years to come.

This process represents a culmination of existing national government goals announced in 2012, when it announced a plan to increase protected areas to include $30 \%$ of its marine EEZ ("The Initiative," 2019). Seychelles adopted a mapping methodology using international best practices, adapting UNESCO [64] recommendations. To determine which marine areas would be protected and what sustainable activities would be permitted, the MSP incorporated the input of 10 ministries and 100 public stakeholders who participated through 9 public workshops and 60 consultations.

To ensure the program's viability, the government of the Seychelles led a mapping process, the Seychelles Marine Spatial Planning (MSP) initiative, beginning in 2014 ("Seychelles Marine," n.d.). The MSP has been a deliberately time-consuming process in order to ensure an evidence-based outcome with sufficient public input. In fact, while Phase I was completed in 2018, protecting $15 \%$ of the Exclusive Economic Zone (EEZ), Phase II is not expected to finish until the end of 2020 ("The Initiative," 2019). 


\subsection{Analysis of SDG15-Related Governance Structure}

\subsubsection{Survey and Assessment of Practices in China}

\subsubsection{Governance Structure}

China has integrated biodiversity into the target system for building an Ecological Civilization, and has been constantly improving the system and institutional settings for biodiversity conservation. It employs a system characterized by unified national regulation and division of responsibilities and cooperation among different sectors to protect biodiversity. In particular, right after it approved the CBD in 1993, China established a Coordinating Group for the Implementation of CBD, with the former State Environmental Protection Administration (SEPA) as the leading agency and the participation of 20 departments/line ministries under the Chinese State Council. It founded a CBD implementation office in the then SEPA and identified the national focal points for CBD implementation, biodiversity clearing-house mechanism, and biosafety respectively. An inter-ministerial Joint Meeting for Protection of Biological Resources was set up at the same time. The Coordinating Group meets every year to develop an annual work plan for CBD implementation and launches a variety of activities. So far, an initial national working mechanism has been formed for biodiversity conservation and CBD implementation. China started the development of a China Biodiversity Conservation Action Plan in 1992 and released the finalized document in 1994. This Action Plan has identified both the location of ecosystems and the list of species for priority conservation, and set out the goals for seven areas of biodiversity conservation in China.

In 2010, the State Council of China founded the "China National Committee for the 2020 International Year of Biodiversity". During its meeting, the State Council reviewed and approved the China Action Plan for the International Year of Biodiversity and the China National Biodiversity Conservation Strategy and Action Plan (2011-2030). In June 2011, the State Council decided to rename the "China National Committee for the International Year of Biodiversity 2010" as the "China National Committee for Biodiversity Conservation", and designated the Vice Premier of the State Council in charge of environment as the Director of the Committee. At present, this Committee has 23 member departments/ministries. It is mandated to coordinate all biodiversity conservation efforts in China, and direct the implementation of China actions for UN Decade on Biodiversity. The establishment of the China National Committee for Biodiversity Conservation shows China's determination to strengthen environmental protection and promote sustainable development, and its commitment to the international community. Since 2015, China has promulgated or revised 56 policies, laws and regulations related to biodiversity conservation, with the policy and legislative system for biodiversity conservation in China gradually improving.

In addition to the governance structure at central level, the environmental protection agencies of the governments at provincial level have also been carrying out 
reforms to better protect biodiversity. In 2008, SEPA was upgraded to the Ministry of Environmental Protection (MEP) and became a department of the State Council. All the provinces, autonomous regions, and municipalities have upgraded their environmental protection agencies to departments, building a unified environmental protection system. Referring to the responsibility and function orientation related to biodiversity conservation at the national level, some provincial governments have established relevant coordination mechanisms, specifying the leading role of environmental protection departments in biodiversity conservation and the corresponding responsibilities of multiple internal agencies within those departments. To go with the actual local conditions, some provinces have set up administration agencies in line with the needs of local biodiversity conservation. For example, Yunnan Province has set up a Lake Protection and Administration Division, showing the local features of its institutional reform and biodiversity conservation. In 2018, in accordance with the "Decision of the Central Committee of the Communist Party of China on Deepening the Reform of the Party and Government Institutions", the Chinese State Council established the new MEE to practice the holistic thinking of integrated management of mountains, waters, forests, farmlands, lakes, and grasslands. All provinces, autonomous regions and municipalities have formed their new Department of Ecological Environment to comprehensively guide, coordinate and supervise the work of eco-environmental protection.

Other major institutions mainly include the China Biodiversity Conservation and Green Development Foundation (CBCGDF), the China National Committee for Biodiversity Conservation, and the Biodiversity Committee of the China Academy of Sciences.

\subsubsection{Green Belt and Road and Biodiversity Conservation}

In the light of China's experience in biodiversity conservation and need for building a green BRI, early efforts to align green BRI and biodiversity conservation have seen growth in the areas of governance mechanisms, governance system, information, technology development and scientific research, as well as green investment and finance, so as to jointly promote biodiversity conservation and implementation of SDG 15 in BRI participating countries.

First, there was a focus on establishing a mechanism and platform for cooperative governance to enable the improvement of a governance system for biodiversity conservation in BRI participating countries. Important progress began to show in integrating the existing bilateral and multilateral international cooperation mechanisms with green Belt and Road, building a network for biodiversity conservation, innovating cooperative models, as well as formulating a cooperation platform with inclusive participation of multiple stakeholders, including national governments, think tanks, business, civil societies and the wide participation of the public. Meanwhile, it is necessary to give full play to the mechanisms established for China-ASEAN cooperation, the Shanghai Cooperation Organization (SCO), the Lancang-Mekong cooperation, the Conference on Interaction and Confidence Building Measures in 
Asia, Euro-Asia Economic Forum, the Forum on China-Africa Cooperation, and the China-Arab States Cooperation Forum among other cooperative platforms. Efforts are still needed to facilitate the establishment of environmental cooperation platforms for the six major Economic Corridors, and expand cooperation with relevant international organizations and agencies, so as to promote the effective implementation of SDG 15.

Second, efforts have been made to enhance cooperation on green technologies and research and development. There is a growing demand for the transfer of green, advanced and applicable technologies in developing countries along the Belt and Road, as well as need for joint research and development, promotion and application of cutting-edge technologies on the conservation of biodiversity. Specifically, further actions are to be taken for a platform on scientific research and technology development across scientific and research institutions and think tanks. Joint research with relevant countries and regions on biodiversity is a favorable opportunity for the conservation of global biodiversity. With the scientific study over the biodiversity of countries and regions along the Belt and Road, it would contribute to the analysis on the biodiversity evolution mechanisms and its characteristics and patterns on geographical distribution in these regions, expedite the scientific research on global diversity and help to provide training and capacity building for young officials and scientists in countries along the Belt and Road.

Third, steps are emerging to promote information exchanges, including biodiversity-related information sharing and disclosure, as well as provision of comprehensive information as decision-making support and safeguard. Growing needs are observed for enhancing the construction of biodiversity information base on the BRI Environmental Big Data Platform; for the full inclusion of national spatial and information infrastructure; for the exchange and sharing on environmental laws and regulations, policy standards and practices and experience; for enhanced comprehensive cooperation among different national departments and the sharing and disclosure on the ecological and environmental information; and for the improved capacity on risk evaluation and prevention targeting at BRI projects overseas. It is necessary to facilitate cooperation on the ecological and environmental information products, technologies and service to provide comprehensive information support and safeguard for building a green Belt and Road.

Fourth, promising progress has been observed in the development of systems on green investment, green trade and green finance. Green finance systems help to build up the foundation for the long-term run of BRI projects. A good example is the Social Responsibility and Environmental Protection Guidelines for Investments in the ASEAN Region released by China-ASEAN Investment Cooperation Fund (CAF). The document prescribes that when CAF provides consulting services for businesses on overseas investment based on its Environmental and Social Management System Arrangements (ESMS), it could refer to the Performance Standards to identify and manage the impacts of environmental and social risks, clarify the evaluation metrics during the investment process, and continuously monitor the later-stage investment, as a way to facilitate invested enterprises to avoid, ease and manage risks via a sustainable operation way. This Performance Standards covers eight areas 
including biodiversity conservation and the sustainable management of biological and natural resources, which jointly composed the standards that clients should meet on sustainable management of biodiversity through the overseas investment process. Specifically, it includes: (1) checking whether the company understands and deals with the impacts of the project on biodiversity; (2) checking whether the company carries out activities in regions under legal protection; (3) checking whether alien species are introduced in the process of project execution, and checking whether the company has the approval or permission from competent authorities if there are plans on introducing alien species; and (4) checking whether the natural resources, forest and vegetation, fresh water and marine resources utilized by the project can be regenerated and whether the company is dedicated to managing them in a sustainable way.

Fifth, such documents as the Green Investment Principle (GIP) for BRI have been released to enhance green guidance on business activities and encourage businesses to adopt voluntary measures for environmental protection and sustainable development. It is important to motivate environmental business to explore the national markets in BRI participating countries, and guide competitive environmental companies to "go global" in clusters with reference to China's experience and standard in building demonstrative ecological industrial parks, so as to enhance biodiversity conservation, prioritize the in-situ conservation and protection in proximity, and take actions for ecological restoration. Meanwhile, efforts have been taken to guide business to augment the research, development and application of major technologies in addressing climate change.

Sixth, there is an increasing necessity to promote gender equality in the BRI cooperation and strengthen female leadership in biodiversity conservation. Biodiversity and gender are hot topics at the international level. Promoting gender mainstreaming in biodiversity conservation has gained widespread attention from the international community in recent years. Biodiversity and gender have been included in the CBD as a key issue. However, such problems as imperfect mechanisms and weak awareness related to gender exist in biodiversity research in China. In view of such problems, the following steps are thus recommended: set up gender focal points in all departments and establish a cross-sectoral communication and cooperation mechanism for gender mainstreaming to comprehensively enhance institutional capacity building; conduct gender mainstreaming training in biodiversity management departments and institutions to raise basic awareness of staff; as well as consider gender in the policies related to eco-environmental protection and green Belt and Road development, and set up gender indicator in the evaluation system for specific projects. Such practice will also help BRI projects to meet the gender-related international standards and requirements of the host countries, promote people-to-people bond, and enable the development of BRI to move forward steadily. 


\subsubsection{Survey and Assessment of International Practices}

As mentioned in Sect. 8.2, the environmental management in the international systems has evolved rapidly over the last few decades. The same can be said for the enforcement and accountability of those systems. Just as Sect. 8.2.2 profiled the screening and assessment systems of international DFIs, this section profiles the accountability mechanisms of those same bodies.

Across the world, DFIs have mobilized to address SDG 15 and ensure that their activities protect project-affected biodiversity. While Sect. 8.2.2 explained standards and guidelines, this section explains the DFI governance structures that have been adapted to ensure that conservation is sufficiently considered. It compares governance structures as adopted by Chinese policy banks' peers: major DFIs, both multilateral as well as national in nature. It includes: AfDB, ADB, AIIB, EBRD, EIB, IADB, IFC, KfW, and the World Bank.

\subsubsection{Governance for Biodiversity: Incorporating SDG15 into DFI Decision-Making}

As explained in Sect. 8.2.2, most major DFIs incorporate biodiversity considerations into their operations through the use of set standards, mitigation hierarchy deployment, and consultations with affected stakeholders, who are likely to depend upon the local ecosystem for their livelihoods and therefore be particularly attuned to any biodiversity threats. In addition to these processes, several DFIs also incorporate other steps to mainstream SDG 15 . These approaches are varied across DFIs. However, commonalities do arise in the requirements that DFIs set for themselves in this aspect, including:

- Incorporating expertise into assessments: the AfDB and AIIB require input from qualified experts to identify potentially-impacted ecosystems and ecosystem services.

- Empowering project implementers to adapt to changing conditions: AfDB, AIIB, EIB, and the World Bank all require the use of adaptive management in their projects. In this approach, borrowers and clients must allow for the possibility that as they develop their projects, conditions will not be what they initially expected. Newly-discovered species or other biodiversity-related project impacts may emerge. Project plans should specify what types of challenges may arise, and how the project implementers will adapt to these changing circumstances. With this planning done, implementers are empowered to change plans during the course of the project. In the case of the AIIB, major changes require additional environmental assessments to ensure that they are adapting their plans adequately. 


\subsubsection{Policy Implementation: Monitoring and Reporting}

Borrowers and clients may commit to responsible environmental management, and DFIs strive to consider the implications for biodiversity, but actual performance will determine final outcomes. To this end, DFIs often institute monitoring and reporting requirements for their borrowers and clients. In doing so, DFIs often emphasize their respect for the national sovereignty of borrowing nations, devising methods that prioritize collaboration between lender and borrower for the best possible outcomes. Several different approaches emerge among DFIs, ranging from those that give borrowers the most responsibility in monitoring to those that utilize outside auditors.

\subsubsection{Policy Implementation: Grievance Mechanisms}

Many DFIs - multilateral as well as national-have instituted policies for stakeholders, including independent NGOs and project beneficiaries, to file grievances and request an investigation if they suspect that biodiversity has been harmed in the pursuit of DFI-supported projects. By developing institutional mechanisms for hearing, investigating, and ruling on these claims, DFIs can ensure that their borrowers and grantees are living up to the terms of the agreement, prevent small harms from ballooning into larger harms, protect their own reputation globally, learn from their experiences, and incorporate these lessons into future activities.

These grievance mechanisms can be at the DFI level, the project level, or both. Project-level grievance mechanisms allow greater flexibility, by promoting the resolution of problems in a way that is often faster and more accessible for stakeholders than relying on one centralized system for claims from projects all around the world. However, they can be more cumbersome for DFIs to manage, requiring oversight of processes in many different countries. The common elements in the design of project-level grievance mechanisms include: design architecture, institutional location, processes, and treatment of claimants.

DFI-level grievance mechanisms allow for stakeholders to bring a claim to the central DFI body, or its designated complaint mechanism, for consideration. These mechanisms can be simpler to manage for DFIs, as they only entail the creation and management of one body. However, they can be less accessible for project-affected stakeholders, and may mean that some rulings take more time than they would in project-level mechanisms.

Table 4.1, in Annex 4, shows the various policy elements that DFIs incorporate into their project-level grievance mechanisms. A wide variety of arrangements exist, enabling DFIs to learn from these examples in designing their own mechanisms.

All of the DFIs listed in Table 4.1 also have DFI-level grievance mechanisms, though their design is too varied to display in table form. In addition to these DFIs, several other major multilateral and national development banks have these mechanisms, including the IADB, CAF, and Brazil's National Bank for Economic and Social Development (BNDES). 


\subsubsection{Incorporating Gender}

Regardless of the venue used, international DFIs have learned the importance of ensuring that accountability mechanisms are accessible for women. In many rural, poor settings, women's property rights are limited, such that ownership is recorded through their fathers, husbands, or sons. In these contexts, national justice systems may not recognize their standing to bring a complaint through local courts, as they may not be able to demonstrate a loss to the value of their property. However, if their concerns are not heard, gender-based biodiversity risks may be unheeded and worsen. Both the ADB and the World Bank have recommended that their projects ensure accessibility for women to their accountability mechanisms, regardless of property [65]. This stage completes the upstream-to-downstream inclusion of gender considerations in biodiversity finance, to ensure that women are not disproportionately impacted in ways that can limit their ability to act as biodiversity stewards at the local level. Table 8.3 collects best practices from international DFIs on incorporating gender throughout the entire project cycle. It is not intended to be a comprehensive list but rather a collection of common best practices as recorded by research and evaluation staff at DFIs worldwide.

\subsection{Policy Recommendation: Construction Roadmap of Green Belt and Road}

The research team has described in the previous content the progress that has been made within China and among China's peers in balancing the benefits of investment with the risks to communities and the ecosystems that support them. Given the speed and scope of this institutional progress, it is crucial to harness all of the lessons possible for additional growth, in order to ensure that the BRI fulfills its potential to support sustainable development globally. Built on the results of the first phase of SPS on Green Belt and Road and 2030 Agenda for Sustainable Development, this section further improves the roadmap for building a green BRI and proposes policy recommendations for aligning BRI and SDG 15. 


\subsubsection{Roadmap for Building a Green BRI}

\subsubsection{Enhancing Policy Communication, and Taking the Green Belt and Road Initiative as an Important Practice of Realizing Sustainable Development Goals and Facilitating Global Environment Governance Reform}

It is important to set green development as the fundamental principles of building the Belt and Road. China has the opportunity to integrate green development and ecological civilization through the "five connectivities" in building the Belt and Road, facilitate the construction of green infrastructure, green investment and green finance, and build the Belt and Road into one route towards green and sustainable development so as to establish a community with shared future for mankind on the basis of green development.

China should augment cooperation in the domain of environmental protection on international multilateral platforms for BRI. Specifically, it is necessary to incorporate the Thematic Forum on Green Silk Road as a fixed thematic forum within the schedule of the Belt and Road Forum for International Cooperation (BRF). It is necessary to bring into full play the role of the BRI International Green Development Coalition and the Belt and Road Sustainable Cities Alliance in serving as the international platforms for jointly developing the Green Silk Road, facilitating the realization of SDGs, and improving global environmental governance system. Efforts are recommended to disseminate the concepts and practice of green development in BRI participating countries via champion countries, pilot cities, and demo projects. In addition, China should make good use of BRI's strengths in the five connectivities to jointly facilitate the implementation of policies on ecological and environmental protection, biodiversity conservation, climate change mitigation and adaptation etc. to bolster support for existing international conventions such as CBD, the Convention on International Trade in Endangered Species of Wild Fauna and Flora (CITES), UNFCCC, etc.

\subsubsection{Enhancing Strategic Alignment and Establishing the Mechanism for Linking Green BRI with the 2030 Agenda for Sustainable Development}

Given that a green BRI is a crucial tool in realizing the 2030 Agenda for Sustainable Development and in particular promoting international biodiversity conservation, this SPS recommends the following steps to strategically align planning with biodiversity goals:

Enhance policy design. This report recommends that China incorporate the implementation of the 2030 Agenda for Sustainable Development (SDGs) as an important task into building a green Belt and Road. When signing MOUs on jointly building the 
Belt and Road with relevant countries and international organizations, China needs to include jointly building a green Belt and Road and expediting the alignment of BRI and the 2030 Agenda as an important part of these MOUs.

Establish a mechanism for implementation. This report recommends setting up working groups/expert teams with partners based on the situations in different countries and jointly draft strategies for building a Green Silk Road together, identifying the priority areas for cooperation in both the short and long terms and fostering sound linkages between different national plans based on the practical needs of implementing SDGs in BRI participating countries.

Develop mechanisms for participation and feedback. A network should be built with government guidance, business support and public participation, prioritizing the perfection of mechanisms on the involvement of international organizations. Initiate the mechanism for whole-process participation, covering negotiation, decision making and dynamic feedback, in order to make sure the successful alignment of building green Belt and Road and implementing the 2030 Agenda for Sustainable Development under open and transparent circumstances.

Establish professional mechanisms for cooperation for cities and localities along the Belt and Road. Cities along the Belt and Road should be encouraged to consider their own industrial structure, advantages, and development goals, and create a policy framework favorable for addressing issues of common concern to explore opportunities for cooperation and guide private sector in participating BRI cooperation.

\subsubsection{Improving Project Management, Establishing and Improving the Mechanism for Project Management on Green Belt and Road}

To incorporate the above-mentioned strategies into BRI project management, this SPS recommends the following steps:

Establish a mechanism for risk evaluation and management of BRI projects. It is important to strengthen communication and coordination between China and BRI participating countries and that among different Chinese government agencies. China should establish science-based risk evaluation and management mechanisms for their projects to respond to various risks, strictly follow the host countries' norms and standards in such procedures as project design, construction, operation, procurement, and bidding. An encouraging environment should be created for BRI projects to apply the principles, standards, and customary practices for environmental protection that are used by international organizations and multilateral financial institutions, and strive to realize goals that are made with high standards, beneficial for people's livelihoods and sustainable. China needs to support its financial institutions to incorporate the ecological and environmental impacts of projects as a key factor in their project rating and risk rating systems, and put forward evaluation methods and instruments 
on the environmental and social risks for BRI projects as an important metric for granting governmental support, development financial support, and policy financial support. Practice in commercial finance is encouraged to adopt similar standards.

Call for wide application of green finance instruments under the Belt and Road framework. First, establishment of the Belt and Road Green Development Fund needs to be explored, with priority given to projects in support of the development of ecological and environmental infrastructure, capacity building and green industries in countries along the Belt and Road. Second, it is necessary to establish guarantee agencies on green investment and financing under the BRI with the wide participation of different countries, in order to share risks and mobilize social capital in green domains. Third, there is a need to establish the mechanism for environmental information disclosure, and enhance the transparency of information based on the BRI Environmental Big Data Platform.

Speed up facilitation of trade in environmental products and services. Improve the opening level of environmental products and services market, encourage enhanced import and export of environmental products and services such as pollution prevention and treatment technologies and services, and help foster green industrial development in BRI participating countries.

\subsubsection{Improving Capacity Building, Jointly Conducting Green Capacity Building Programs with BRI Participating Countries}

With regard to public engagement, this SPS recommends that BRI project planners take the following steps:

Enhance people-to-people bonds among BRI participating countries. The Green Silk Road Envoys Program should be expanded into a flagship program on capacity building under the Belt and Road framework, which aims to enhance ecological and environmental cooperation and communications and share the ideas and practices of building an Ecological Civilization and green development in China via such activities as capacity building workshops for environmental officials, managers, and practitioners, consultation for policy development, etc.

Support and facilitate the exchange and cooperation of environmental organizations from China and BRI participating countries. The first step is to clarify the leading and responsible government department, and then guide/support environmental organizations to build up their own cooperation networks. In addition, efforts are needed to perfect the mechanism for the involvement of environmental social organizations and come up with a list of items on international communication with the participation of environmental organizations.

Facilitate gender mainstreaming and augment women's leadership roles. There is a necessity to improve gender consciousness among policy makers and women communities and facilitate the mainstreaming of gender consciousness in the process 
of policy formulation and project implementation for building a green Belt and Road. This report recommends enhancing institutional capacity building on gender mainstreaming in environmental protection related agencies, and explore the possibility of establishing a cross-sectoral communication mechanism to facilitate gender mainstreaming. With the help of the Green Silk Road Envoys Program, China could organize thematic capacity building programs and seminars on improving women's leadership roles in green development upon inviting the participation of female officials, experts, scholars and youth in the domain of environmental protection from BRI participating countries, and share methods and experience in gender mainstreaming with BRI partners.

\subsubsection{Policy Instruments for Aligning the BRI with SDG 15}

Under the framework and in the spirit of the general roadmap for building a green BRI outlined above, this session recommends the policy directions for aligning BRI, SDG 15 , and CBD. The proposed policy recommendations are built with full consideration of the main objective and approaches internationally used for biodiversity conservation. The main objective is focusing on the establishment and mainstreaming of global standards, which are primarily practiced through the establishment of operational risk management strategies to protect institutional reputations and the cooperative relationships. The corresponding major approaches for operationalizing standards include: (1) aligning institutional practices with international or national commitments, (2) using exclusionary lists of categorically ineligible projects, (3) requiring projects to undergo biodiversity impact assessments, (4) adopting a mitigation hierarchy to do no harm and if possible benefit local ecosystems, and (5) incorporate local stakeholders.

The following four policy directions are thus proposed:

First, apply international norms and standards to facilitate the use of stricter environmental standards in BRI projects. The BRI projects should comply with the environmental laws, regulations and standards of the host country. These projects are encouraged to adopt environmental protection principles, standards and practices implemented by international organizations and multi-lateral financial institutions. It is recommended to actively align BRI efforts with the fulfillment of international and national commitments to international conventions, including the Convention on Biological Convention and the United Nations Framework Convention on Climate Change. It is also necessary to align BRI with other biodiversity related international conventions that China is a signatory to such as the International Convention for the Protection of New Varieties of Plants, Convention Concerning the Protection of the World Cultural and Natural Heritage, Convention on International Trade in Endangered Species of Wild Fauna and Flora, Convention on Wetlands of International Importance Especially as Waterfowl Habitat, and achieve synergies with climate related conventions like UNFCCC. 
Second, focus on environmental impacts and carry out assessment and classification-oriented management of BRI projects. It is recommended to boost the development of the guidance on assessment and classification of BRI projects, which should include clearly defined positive and negative lists, in order to give adequate attention to the projects' potential impacts related to environmental pollution, biodiversity conservation, and climate change based on the ongoing Joint Research on Green Development Guidance for BRI Projects undertaken by BRIGC, which could provide green solutions to BRI participating countries and projects and provide green credit guidelines to financial institutions. It is recommended to pilot concept and practice of green development via champion countries, pilot cities and demo projects and enhance BRI green development case studies and experience sharing. The research on Green Development Guidance for BRI Projects shows that the assessment- and classification-oriented management should consider the various international and national commitments of the host countries, and meet the host countries' needs for economic growth and environmental protection. Such management should guide and assist businesses to incorporate environmental impact assessment (EIA), as well as biodiversity conservation and impact mitigation measures at the stage of project design.

Besides, it is important to adopt a mitigation hierarchy for those projects identified as having significant biodiversity risks as a result of strategic environmental assessment (SEA). Given such international practice, drawing on its own experience with the ecological redlining, biodiversity offsets, ecological restoration, and ecological compensation schemes, China is recommended to develop a standardized biodiversity conservation hierarchy that should include four components of "avoidance", "mitigation", "restoration", and "compensation".

Third, improve policy instruments to prevent and control the eco-environmental risks related to BRI projects. These instruments include the following three aspects.

- It is recommended to carry out environmental impact assessment for key BRI sectors and projects and establish a regular environmental risk regulatory mechanism. The biodiversity analysis should fully examine the ecological and socioeconomic conditions of the project locality, gauge the direct, indirect and cumulative impacts of the project on wildlife habitats and biodiversity, and consider how the project-affected stakeholders value biodiversity and wildlife habitats.

- It is recommended to make full use of green finance instruments and environmental risk assessment tools, establish biodiversity conservation governance and financing framework, and give full play to the proactive role of financial institutions in guiding green investment. Given that biodiversity conservation requires an enabling policy environment, the MEE should be charged to work with the NDRC and other administrative bodies to design biodiversity impacts mitigation strategies and to jointly design financing mechanisms for mitigation, compensation, and restoration schemes in consultation with various stakeholders in the Chinese government, host countries, and other affected parties and partners.

- It is recommended to take ecological redlining as a key instrument to align the BRI and SDG 15 and share best practices in ecological redlining with participating 
countries. It is important to support the BRI participating countries to build on the experience of ecological redlining in developing similar land use strategic planning.

Fourth, improve the coordination mechanism and facilitate effective linkage and alignment among different SDGs using Nation-based Solutions (NBS). It is important to create synergies with efforts for SDG 13 of Climate Action, consider a step-by-step reduction of investments in carbon-intensive industries such as coalfired power plants to prevent carbon lock-in, and further strengthen investments in green projects on environmental protection and renewable energy to encourage environmentally-sustainable, green and low-carbon projects. The concept of green development should be incorporated into the selection, implementation and management of infrastructure projects with strengthened efforts being made in researching and developing the guidelines on sustainable infrastructure operation.

\section{Annex 1: Supporting Evidence for Chapter 1}

Table A1-1 Geographic distribution of countries that have signed BRI memorandums of understanding

\begin{tabular}{l|l}
\hline Region & BRI Countries \\
\hline East Asia & Republic of Korea, Mongolia \\
\hline $\begin{array}{l}\text { ASEAN countries } \\
\text { (10 countries) }\end{array}$ & $\begin{array}{l}\text { Singapore, Malaysia, Indonesia, Myanmar, Thailand, } \\
\text { Laos, Cambodia, Viet Nam, Brunei, Philippines }\end{array}$ \\
\hline $\begin{array}{l}\text { West Asia } \\
\text { 17 countries) }\end{array}$ & $\begin{array}{l}\text { Iran, Iraq, Turkey, Syria, Jordan, Lebanon, Israel, Saudi } \\
\text { Arabia, Yemen, Oman, UAE, Qatar, Kuwait, Bahrain, } \\
\text { Greece, Cyprus, and Sinai Peninsula of Egypt }\end{array}$ \\
\hline $\begin{array}{l}\text { South Asia } \\
\text { (8 countries) }\end{array}$ & $\begin{array}{l}\text { India, Pakistan, Bangladesh, Afghanistan, Sri Lanka, } \\
\text { Maldives, Nepal, Bhutan }\end{array}$ \\
\hline $\begin{array}{l}\text { Central Asia } \\
\text { (5 countries) }\end{array}$ & $\begin{array}{l}\text { Kazakhstan, Uzbekistan, Turkmenistan, Tajikistan, } \\
\text { Kyrgyzstan }\end{array}$ \\
\hline $\begin{array}{l}\text { Commonwealth of Independent States } \\
\text { (7 countries) }\end{array}$ & $\begin{array}{l}\text { Russia, Ukraine, Belarus, Georgia, Azerbaijan, } \\
\text { Armenia, Moldova }\end{array}$ \\
\hline $\begin{array}{l}\text { Central and Eastern Europe } \\
\text { (16 countries) }\end{array}$ & $\begin{array}{l}\text { Poland, Lithuania, Estonia, Latvia, Czech Republic, } \\
\text { Slovakia, Hungary, Slovenia, Croatia, Bosnia and } \\
\text { Herzegovina, Montenegro, Serbia, Albania, Romania, } \\
\text { Bulgaria, Macedonia }\end{array}$ \\
\hline $\begin{array}{l}\text { Western Europe (7 countries) } \\
\text { Pustria, Finland, France, Italy, Luxembourg, Malta, } \\
\text { Portugal }\end{array}$ \\
\hline $\begin{array}{l}\text { North Africa } \\
\text { (5 countries) }\end{array}$ & \begin{tabular}{l} 
Algeria, Libya, Mauritania, Morocco, Tunisia \\
\hline
\end{tabular} \\
\hline
\end{tabular}


(continued)

\begin{tabular}{l|l}
\hline Region & BRI Countries \\
\hline $\begin{array}{l}\text { West Africa } \\
\text { 11 countries })\end{array}$ & $\begin{array}{l}\text { Cabo Verde, Cote d'Ivoire, The Gambia, Ghana, } \\
\text { Guinea, Liberia, Mali, Nigeria, Senegal, Sierra Leone, } \\
\text { Togo }\end{array}$ \\
\hline $\begin{array}{l}\text { Central and Southern Africa } \\
\text { (8 countries })\end{array}$ & $\begin{array}{l}\text { Angola, Cameroon, Chad, Republic of Congo, } \\
\text { Equatorial Guinea, Gabon, Namibia, South Africa }\end{array}$ \\
\hline $\begin{array}{l}\text { East Africa } \\
(15 \text { countries })\end{array}$ & $\begin{array}{l}\text { Burundi, Djibouti, Ethiopia, Kenya, Madagascar, } \\
\text { Mozambique, Rwanda, Seychelles, Somalia, South } \\
\text { Sudan, Sudan, Tanzania, Uganda, Zambia, Zimbabwe }\end{array}$ \\
\hline $\begin{array}{l}\text { Latin America } \\
(11 \text { countries })\end{array}$ & $\begin{array}{l}\text { Bolivia, Chile, Costa Rica, Ecuador, El Salvador, } \\
\text { Guyana, Panama, Peru, Suriname, Uruguay, Venezuela }\end{array}$ \\
\hline $\begin{array}{l}\text { Caribbean } \\
(8 \text { countries })\end{array}$ & $\begin{array}{l}\text { Antigua and Barbuda, Barbados, Cuba, Dominica, } \\
\text { Dominican Republic, Grenada, Jamaica, Trinidad and } \\
\text { Tobago }\end{array}$ \\
\hline $\begin{array}{l}\text { Oceania } \\
(9 \text { countries })\end{array}$ & $\begin{array}{l}\text { Fiji, Kiribati, Micronesia, New Zealand, Papua New } \\
\text { Guinea, Samoa, Solomon Islands, Tonga, Vanuatu }\end{array}$ \\
\hline
\end{tabular}

Note Timor-Leste is currently in the process of ASEAN accession 
Table A1-2. The state of BRI countries in implementing SDG 15

\begin{tabular}{|c|c|c|c|c|c|c|c|}
\hline Region & Country & $\begin{array}{c}\text { Goal } 15 \\
\text { Implemen- } \\
\text { tation }\end{array}$ & $\begin{array}{c}\text { Goal } \\
15 \\
\text { Trend }\end{array}$ & Region & Country & $\begin{array}{l}\text { Goal } 15 \\
\text { Implemen- } \\
\text { tation }\end{array}$ & $\begin{array}{c}\text { Goal } \\
15 \\
\text { Trend }\end{array}$ \\
\hline \multirow{3}{*}{$\begin{array}{l}\text { East } \\
\text { Asia }\end{array}$} & \multirow[t]{2}{*}{ Mongolia } & & \multirow[t]{2}{*}{$\underline{x}$} & \multirow{8}{*}{$\begin{array}{l}\text { West } \\
\text { Asia }\end{array}$} & Bahrain & & . \\
\hline & & & & & Lebanon & & $\rightrightarrows$ \\
\hline & Republic of Korea & & $\rightrightarrows$ & & Qatar & & . \\
\hline \multirow{10}{*}{ ASEAN } & Singapore & & . & & Iran & & $\underline{\perp}$ \\
\hline & Indonesia & & $\downarrow$ & & $\begin{array}{l}\text { Sinai Peninsula, } \\
\text { Egypt }\end{array}$ & & $\rightrightarrows$ \\
\hline & Malaysia & & $\rightrightarrows$ & & Cyprus & & . \\
\hline & Cambodia & & $\downarrow$ & & Greece & & $\underline{x}$ \\
\hline & Vietnam & & $\underline{I}$ & & Jordan & & . \\
\hline & Myanmar & & $\downarrow$ & \multirow{16}{*}{$\begin{array}{c}\text { Central } \\
\text { and } \\
\text { Eastern } \\
\text { Europe }\end{array}$} & Montenegro & & $\downarrow$ \\
\hline & Lao P. D. R. & & $\downarrow$ & & Serbia & & $\underline{\pi}$ \\
\hline & Philippines & & $\downarrow$ & & Bosnia and Herz. & & $\rightrightarrows$ \\
\hline & Thailand & & $\rightrightarrows$ & & N. Macedonia & & $\underline{1}$ \\
\hline & Brunei & & . & & Croatia & & $\underline{1}$ \\
\hline \multirow{8}{*}{$\begin{array}{l}\text { South } \\
\text { Asia }\end{array}$} & Maldives & & . & & Albania & & $\underline{7}$ \\
\hline & India & & $\downarrow$ & & Slovenia & & $\uparrow$ \\
\hline & Afghanistan & & $\downarrow$ & & Romania & & $\uparrow$ \\
\hline & Bhutan & & $\rightrightarrows$ & & Slovakia & & $\uparrow$ \\
\hline & Bangladesh & & $\downarrow$ & & Hungary & & $\uparrow$ \\
\hline & Sri Lanka & & $\underline{1}$ & & Lithuania & & $\uparrow$ \\
\hline & Pakistan & & $\downarrow$ & & Estonia & & $\uparrow$ \\
\hline & Nepal & & $\rightrightarrows$ & & Czech Republic & & $\uparrow$ \\
\hline \multirow{5}{*}{$\begin{array}{l}\text { Central } \\
\text { Asia }\end{array}$} & Turkmenistan & & $\rightleftarrows$ & & Poland & & $\uparrow$ \\
\hline & Kazakhstan & & $\rightleftarrows$ & & Latvia & & $\uparrow$ \\
\hline & Uzbekistan & & $\rightrightarrows$ & & Bulgaria & & $\uparrow$ \\
\hline & Kyrgyzstan & & $\rightrightarrows$ & \multirow{7}{*}{$\begin{array}{c}\text { Comm. } \\
\text { of } \\
\text { Indep. } \\
\text { States }\end{array}$} & Georgia & & $\rightleftarrows$ \\
\hline & Tajikistan & & $\rightrightarrows$ & & Armenia & & $\downarrow$ \\
\hline \multirow{9}{*}{$\begin{array}{l}\text { West } \\
\text { Asia }\end{array}$} & Iraq & & $\rightrightarrows$ & & Ukraine & & $\rightrightarrows$ \\
\hline & Kuwait & & . & & Moldova & & $\rightrightarrows$ \\
\hline & United Arab Emir. & & . & & Russian. & & $\rightrightarrows$ \\
\hline & Saudi Arabia & & $\rightleftarrows$ & & Azerbaijan & & $\rightrightarrows$ \\
\hline & Syria & & $\rightrightarrows$ & & Belarus & & $\uparrow$ \\
\hline & Israel & & $\downarrow$ & \multirow{4}{*}{$\begin{array}{l}\text { Western } \\
\text { Europe }\end{array}$} & Luxembourg & & $\underline{\lambda}$ \\
\hline & Yemen & & $\downarrow$ & & Malta & & . \\
\hline & Oman & & . & & Austria & & $\underline{1}$ \\
\hline & Turkey & & $\rightrightarrows$ & & Portugal & & $\underline{1}$ \\
\hline
\end{tabular}


(continued)

Table A1-2, continued: The state of BRI countries in implementing SDG 15

\begin{tabular}{|c|c|c|c|c|c|c|c|}
\hline Region & Country & $\begin{array}{c}\text { Goal } 15 \\
\text { Implemen- } \\
\text { tation }\end{array}$ & $\begin{array}{c}\text { Goal } \\
15 \\
\text { Trend }\end{array}$ & Region & Country & $\begin{array}{l}\text { Goal } 15 \\
\text { Implemen- } \\
\text { tation }\end{array}$ & $\begin{array}{c}\text { Goal } \\
15 \\
\text { Trend }\end{array}$ \\
\hline \multirow{3}{*}{$\begin{array}{l}\text { Western } \\
\text { Europe }\end{array}$} & France & & $\underline{x}$ & \multirow{7}{*}{$\begin{array}{l}\text { West } \\
\text { Africa }\end{array}$} & Senegal & & \\
\hline & Finland & & $\uparrow$ & & The Gambia & & . \\
\hline & Italy & & $\uparrow$ & & Ghana & & \\
\hline \multirow{5}{*}{$\begin{array}{l}\text { North } \\
\text { Africa }\end{array}$} & Algeria & & $\rightrightarrows$ & & Cote d'Ivoire & & $\underline{x}$ \\
\hline & Tunisia & & $\underline{1}$ & & Nigeria & & $\underline{-}$ \\
\hline & Mauritania & & . & & Guinea & & $\underline{x}$ \\
\hline & Morocco & & $\rightrightarrows$ & & Togo & & . \\
\hline & Libya & & . & \multirow{11}{*}{$\begin{array}{c}\text { Latin } \\
\text { America }\end{array}$} & Uruguay & & $\underline{\downarrow}$ \\
\hline \multirow{15}{*}{$\begin{array}{c}\text { East } \\
\text { Africa }\end{array}$} & Djibouti & & $\downarrow$ & & Panama & & . \\
\hline & Madagascar & & $\rightrightarrows$ & & Chile & & $\downarrow$ \\
\hline & Ethiopia & & $\rightrightarrows$ & & Guyana & & . \\
\hline & Tanzania & & $\rightrightarrows$ & & Ecuador & & $\rightrightarrows$ \\
\hline & Kenya & & $\downarrow$ & & El Salvador & & $\rightleftarrows$ \\
\hline & Sudan & & $x$ & & Costa Rica & & . \\
\hline & Rwanda & & $\rightrightarrows$ & & Peru & & . \\
\hline & Mozambique & & $\Longrightarrow$ & & Suriname & & $\underline{-}$ \\
\hline & Uganda & & $\underline{1}$ & & Bolivia & & $\underline{\pi}$ \\
\hline & Zambia & & $\rightrightarrows$ & & Venezuela & & $\underline{x}$ \\
\hline & Burundi & & $\uparrow$ & \multirow{8}{*}{ Caribbean } & Jamaica & & . \\
\hline & Zimbabwe & & $\underline{x}$ & & Trin. \& Tobago & & . \\
\hline & Seychelles & & . & & Cuba & & . \\
\hline & Somalia & & $\rightleftarrows$ & & Dominican Rep. & & $\underline{1}$ \\
\hline & South Sudan & & $\underline{-}$ & & Antigua \& Barb. & & . \\
\hline \multirow{8}{*}{$\begin{array}{l}\text { Central } \\
\text { and } \\
\text { Southern } \\
\text { Africa }\end{array}$} & South Africa & & $\underline{1}$ & & Barbados & & . \\
\hline & Angola & & $\rightrightarrows$ & & Dominica & & . \\
\hline & Cameroon & & $\rightrightarrows$ & & Grenada & & $\cdot$ \\
\hline & Chad & & $\uparrow$ & \multirow{9}{*}{ Oceania } & Fiji & & $\downarrow$ \\
\hline & Gabon & & $\uparrow$ & & Vanuatu & & . \\
\hline & Namibia & & $\uparrow$ & & New Zealand & & $\downarrow$ \\
\hline & Congo, Republic & & $\uparrow$ & & P.N.G. & & . \\
\hline & Equatorial Guinea & & . & & Kiribati & & . \\
\hline \multirow{4}{*}{$\begin{array}{c}\text { West } \\
\text { Africa }\end{array}$} & Liberia & & $\rightrightarrows$ & & Micronesia & & . \\
\hline & Cabo Verde & & . & & Samoa & & . \\
\hline & Sierra Leone & & $\uparrow$ & & Solomon Isl. & & . \\
\hline & Mali & & $\rightleftarrows$ & & Tonga & & . \\
\hline
\end{tabular}

(continued) 
(continued)

Table A1-2, continued: Legend

Colors

\begin{tabular}{|l|}
\hline Green \\
\hline Yellow \\
\hline Orange \\
\hline Red \\
\hline
\end{tabular}

Goal Achievement

Challenges Remain

Significant Challenges

Major Challenges

\section{Trend Arrows}

$\uparrow$ On track or Maintaining Achievement

․ Moderately Increasing

$\longrightarrow \quad$ Stagnating

$\pm \quad$ Decreasing

Data not available

\section{Annex 2: Supporting Evidence for Chapter 2}

Table A2-1. Assessment of China's progress in implementing SDG 15

\begin{tabular}{|c|c|c|c|}
\hline SDG15 & $\begin{array}{l}\text { Main work undertaken by } \\
\text { China to achieve SDGs }\end{array}$ & Indicators & $\begin{array}{c}\text { Overall } \\
\text { assessments } \\
\text { and trends }\end{array}$ \\
\hline \multirow{3}{*}{$\begin{array}{l}15.1 \text { By } 2020 \text {, ensure } \\
\text { the conservation, } \\
\text { restoration and } \\
\text { sustainable use of } \\
\text { terrestrial and inland } \\
\text { freshwater } \\
\text { ecosystems and their } \\
\text { services, in particular } \\
\text { forests, wetlands, } \\
\text { mountains and } \\
\text { drylands, in line with } \\
\text { obligations under } \\
\text { international } \\
\text { agreements }\end{array}$} & \multirow{3}{*}{$\begin{array}{l}\text { Safeguarding the ecological } \\
\text { water level of important } \\
\text { wetlands and estuaries, } \\
\text { protecting and restoring wetland } \\
\text { and river and lake ecosystems, } \\
\text { establishing systems of wetland } \\
\text { protection and degraded wetland } \\
\text { protection and restoration, and } \\
\text { promoting the rational use of } \\
\text { wetlands; promoting the } \\
\text { development of the legal system } \\
\text { of terrestrial nature reserves and } \\
\text { improving the level of protection } \\
\text { and utilization of natural } \\
\text { resources such as forests; and } \\
\text { conducting river and lake health } \\
\text { assessments to protect aquatic } \\
\text { ecosystems. }\end{array}$} & $\begin{array}{l}\text { National-level } \\
\text { protected areas for } \\
\text { aquatic germplasm } \\
\text { resources }\end{array}$ & \\
\hline & & $\begin{array}{l}\text { Number of wetland } \\
\text { parks }\end{array}$ & \\
\hline & & $\begin{array}{l}\text { Percentage of } \\
\text { surface water } \\
\text { bodies with good } \\
\text { quality meeting } \\
\text { Classes I-III } \\
\text { standards }\end{array}$ & \\
\hline \multirow{2}{*}{$\begin{array}{l}15.2 \text { By } 2020, \\
\text { promote the } \\
\text { implementation of } \\
\text { sustainable } \\
\text { management of all } \\
\text { types of forests, halt } \\
\text { deforestation, restore } \\
\text { degraded forests and } \\
\text { substantially increase } \\
\text { afforestation and } \\
\text { reforestation globally }\end{array}$} & \multirow{2}{*}{$\begin{array}{l}\text { Carrying out large-scale land } \\
\text { greening, strengthening the } \\
\text { implementation of key } \\
\text { afforestation projects, improving } \\
\text { the natural forest protection } \\
\text { system, comprehensively } \\
\text { stopping commercial forest } \\
\text { logging, and protecting and } \\
\text { cultivating forest ecosystems; } \\
\text { improving the policy of } \\
\text { returning farmlands to forests } \\
\text { and grasslands, and exploring the } \\
\text { establishment of mechanisms for } \\
\text { government-sponsored social } \\
\text { services to carry out } \\
\text { afforestation and forest } \\
\text { protection. }\end{array}$} & Total forest stock & \\
\hline & & $\begin{array}{l}\text { Area of natural } \\
\text { forests }\end{array}$ & \\
\hline
\end{tabular}

(continued) 
(continued)

\begin{tabular}{|c|c|c|c|}
\hline \multirow{3}{*}{$\begin{array}{l}15.3 \text { By } 2030, \\
\text { combat } \\
\text { desertification, } \\
\text { restore degraded land } \\
\text { and soil, including } \\
\text { land affected by } \\
\text { desertification, } \\
\text { drought and floods, } \\
\text { and strive to achieve } \\
\text { a land degradation- } \\
\text { neutral world }\end{array}$} & \multirow{3}{*}{$\begin{array}{l}\text { Participating in demonstration } \\
\text { projects aiming at land } \\
\text { degradation neutrality goal under } \\
\text { the United Nations Convention } \\
\text { to Combat Desertification; } \\
\text { promoting the comprehensive } \\
\text { control of desertification, rocky } \\
\text { desertification and soil erosion, } \\
\text { preventing land degradation, } \\
\text { continuously expanding the } \\
\text { scope of desertification land } \\
\text { management, and strengthening } \\
\text { the ecological protection and } \\
\text { construction of desert areas. }\end{array}$} & $\begin{array}{l}\text { Forest stock in key } \\
\text { ecological project } \\
\text { areas }\end{array}$ & \\
\hline & & $\begin{array}{l}\text { Grassland } \\
\text { vegetation cover } \\
\text { rate in key } \\
\text { ecological project } \\
\text { areas }\end{array}$ & \\
\hline & & $\begin{array}{l}\text { Area of desertified } \\
\text { land }\end{array}$ & \\
\hline \multirow{4}{*}{$\begin{array}{l}15.4 \text { By } 2030 \text {, ensure } \\
\text { the conservation of } \\
\text { mountain ecosystems, } \\
\text { including their } \\
\text { biodiversity, in order } \\
\text { to enhance their } \\
\text { capacity to provide } \\
\text { benefits that are } \\
\text { essential for } \\
\text { sustainable } \\
\text { development }\end{array}$} & \multirow{4}{*}{$\begin{array}{l}\text { Comprehensively improving the } \\
\text { stability of mountain ecosystems } \\
\text { and ecological service functions } \\
\text { and building an ecological } \\
\text { security barrier; constructing } \\
\text { national forest germplasm } \\
\text { resource banks and establishing } \\
\text { a system of standardized } \\
\text { germplasm resource } \\
\text { conservation; scientifically } \\
\text { optimizing the forest park } \\
\text { management system and } \\
\text { promoting the sharing and } \\
\text { utilization of forest diversity } \\
\text { resources. }\end{array}$} & $\begin{array}{l}\text { Number and area of } \\
\text { forest parks }\end{array}$ & \\
\hline & & $\begin{array}{l}\text { Total timber } \\
\text { standing stock }\end{array}$ & \\
\hline & & $\begin{array}{l}\text { Area of natural } \\
\text { forests }\end{array}$ & \\
\hline & & $\begin{array}{l}\text { National } \\
\text { investments in } \\
\text { ecological } \\
\text { conservation }\end{array}$ & \\
\hline \multirow{2}{*}{$\begin{array}{l}15.5 \text { Take urgent } \\
\text { and significant action } \\
\text { to reduce the } \\
\text { degradation of natural } \\
\text { habitats, halt the loss } \\
\text { of biodiversity and, } \\
\text { by } 2020 \text {, protect and } \\
\text { prevent the extinction } \\
\text { of threatened species }\end{array}$} & \multirow{2}{*}{$\begin{array}{l}\text { Implementing major projects for } \\
\text { biodiversity conservation; } \\
\text { strengthening the construction } \\
\text { and management of nature } \\
\text { reserves, and increasing the } \\
\text { protection of typical ecosystems, } \\
\text { species, genes and landscape } \\
\text { diversity; increasing the } \\
\text { investment in ecosystem } \\
\text { protection and restoration and } \\
\text { carrying out large-scale survey } \\
\text { of baselines for species resources } \\
\text { in the country; and establishing a } \\
\text { national biodiversity observation } \\
\text { network. }\end{array}$} & Red List Index & \\
\hline & & Living Planet Index & \\
\hline $\begin{array}{l}15.6 \quad \text { Promote fair } \\
\text { and equitable sharing } \\
\text { of the benefits arising } \\
\text { from the utilization of } \\
\text { genetic resources and } \\
\text { promote appropriate } \\
\text { access to such } \\
\text { resources, as } \\
\text { internationally agreed }\end{array}$ & $\begin{array}{l}\text { Gradually establishing and } \\
\text { improving laws and regulations } \\
\text { on the protection and benefit } \\
\text { sharing of genetic resources and } \\
\text { promoting the proper access to } \\
\text { genetic resources and the fair } \\
\text { and equitable sharing and } \\
\text { utilization; increasing funding } \\
\text { for the conservation of biological } \\
\text { genetic resources and } \\
\text { participating in international } \\
\text { cooperation in access to and use } \\
\text { of genetic resources. }\end{array}$ & $\begin{array}{l}\text { Indicators related to } \\
\text { access to genetic } \\
\text { resources and } \\
\text { benefit-sharing }\end{array}$ & $\circ \circ$ \\
\hline
\end{tabular}




\section{(continued)}

\begin{tabular}{|c|c|c|c|}
\hline $\begin{array}{l}15.7 \text { Take urgent } \\
\text { action to end } \\
\text { poaching and } \\
\text { trafficking of } \\
\text { protected species of } \\
\text { flora and fauna and } \\
\text { address both demand } \\
\text { and supply of illegal } \\
\text { wildlife products }\end{array}$ & $\begin{array}{l}\text { Seriously implementing the Wild } \\
\text { Animal Protection Law and } \\
\text { speeding up the improvement of } \\
\text { the National List of Key } \\
\text { Protected Wild Animals; } \\
\text { optimizing the national wildlife } \\
\text { protection network, } \\
\text { strengthening the import and } \\
\text { export management of wild } \\
\text { animals and plants, and cracking } \\
\text { down on illegal trade in wild } \\
\text { animal and plant products such } \\
\text { as ivory; restoring and } \\
\text { expanding the habitats of } \\
\text { endangered wildlife and } \\
\text { promoting international } \\
\text { cooperation in wildlife } \\
\text { conservation. }\end{array}$ & I & 1 \\
\hline \multirow{3}{*}{$\begin{array}{l}15.8 \text { By } 2020, \\
\text { introduce measures to } \\
\text { prevent the } \\
\text { introduction and } \\
\text { significantly reduce } \\
\text { the impact of } \\
\text { invasive alien species } \\
\text { on land and water } \\
\text { ecosystems and } \\
\text { control or eradicate } \\
\text { the priority species }\end{array}$} & \multirow{3}{*}{$\begin{array}{l}\text { Actively participating in } \\
\text { international conventions related } \\
\text { to the prevention and control of } \\
\text { invasive alien species; improving } \\
\text { the list of IAS and related risk } \\
\text { assessments }\end{array}$} & $\begin{array}{l}\text { Number of newly } \\
\text { discovered IAS } \\
\text { every decade }\end{array}$ & \\
\hline & & $\begin{array}{l}\text { Batches and } \\
\text { number of species } \\
\text { of harmful pests } \\
\text { intercepted at ports }\end{array}$ & \\
\hline & & $\begin{array}{l}\text { Number of IAS risk } \\
\text { assessment } \\
\text { standards released. }\end{array}$ & \\
\hline $\begin{array}{l}15.9 \text { By } 2020, \\
\text { integrate ecosystem } \\
\text { and biodiversity } \\
\text { values into national } \\
\text { and local planning, } \\
\text { development } \\
\text { processes, poverty } \\
\text { reduction strategies } \\
\text { and accounts }\end{array}$ & $\begin{array}{l}\text { Requiring governments of all } \\
\text { levels to undertake ecological } \\
\text { conservation and biodiversity } \\
\text { conservation taking into account } \\
\text { their local circumstances, and to } \\
\text { incorporate biodiversity into } \\
\text { their long-term and medium term } \\
\text { development planning. }\end{array}$ & $\begin{array}{l}\text { Number of sectoral } \\
\text { policies related to } \\
\text { conservation and } \\
\text { sustainable use of } \\
\text { biodiversity }\end{array}$ & \\
\hline $\begin{array}{l}\text { 15.a Mobilize and } \\
\text { significantly increase } \\
\text { financial resources } \\
\text { from all sources to } \\
\text { conserve and } \\
\text { sustainably use } \\
\text { biodiversity and } \\
\text { ecosystems }\end{array}$ & $\begin{array}{l}\text { Strengthening coordination and } \\
\text { increasing funds needed for } \\
\text { infrastructure and capacity } \\
\text { building }\end{array}$ & $\begin{array}{l}\text { National } \\
\text { investments in } \\
\text { ecological } \\
\text { conservation }\end{array}$ & \\
\hline
\end{tabular}

(continued) 
(continued)

\begin{tabular}{|c|c|c|c|}
\hline $\begin{array}{l}\text { 15.b Mobilize } \\
\text { significant resources } \\
\text { from all sources and } \\
\text { at all levels to finance } \\
\text { sustainable forest } \\
\text { management and } \\
\text { provide adequate } \\
\text { incentives to } \\
\text { developing countries } \\
\text { to advance such } \\
\text { management, } \\
\text { including for } \\
\text { conservation and } \\
\text { reforestation }\end{array}$ & $\begin{array}{l}\text { Promoting diversified resource } \\
\text { mobilization strategies, guiding } \\
\text { enterprises and the public to } \\
\text { participate more deeply, and } \\
\text { forming a long-term financial } \\
\text { mechanism for forest } \\
\text { management; helping other } \\
\text { developing countries to carry out } \\
\text { technical training under the } \\
\text { framework of South-South } \\
\text { cooperation to improve the rate } \\
\text { of utilization of forest resources } \\
\text { and the level of forest } \\
\text { management; and guiding } \\
\text { Chinese companies to carry out } \\
\text { sustainable forest management } \\
\text { and business operation abroad. }\end{array}$ & $\begin{array}{l}\text { Ecological } \\
\text { compensation for } \\
\text { forest ecological } \\
\text { benefits }\end{array}$ & \\
\hline $\begin{array}{l}\text { 15.c Enhance } \\
\text { global support for } \\
\text { efforts to combat } \\
\text { poaching and } \\
\text { trafficking of } \\
\text { protected species, } \\
\text { including by } \\
\text { increasing the } \\
\text { capacity of local } \\
\text { communities to } \\
\text { pursue sustainable } \\
\text { livelihood } \\
\text { opportunities }\end{array}$ & $\begin{array}{l}\text { Strengthening the review of } \\
\text { trade in species restricted by the } \\
\text { international trade conventions } \\
\text { in which China participates, and } \\
\text { strictly managing the } \\
\text { certification under the } \\
\text { Convention on International } \\
\text { Trade in Endangered Species of } \\
\text { Wild Fauna and Flora; carrying } \\
\text { out special actions to curb the } \\
\text { criminal momentum of poaching } \\
\text { and illegal trade of wild animals; } \\
\text { and encouraging and guiding the } \\
\text { development of wild plant } \\
\text { artificial cultivation industry. }\end{array}$ & $\begin{array}{l}\text { Number of illegally } \\
\text { smuggled or } \\
\text { trafficked protected } \\
\text { species intercepted } \\
\text { or detected }\end{array}$ & $\circ \circ \circ$ \\
\hline
\end{tabular}


432

8 Green BRI and 2030 Agenda for Sustainable Development

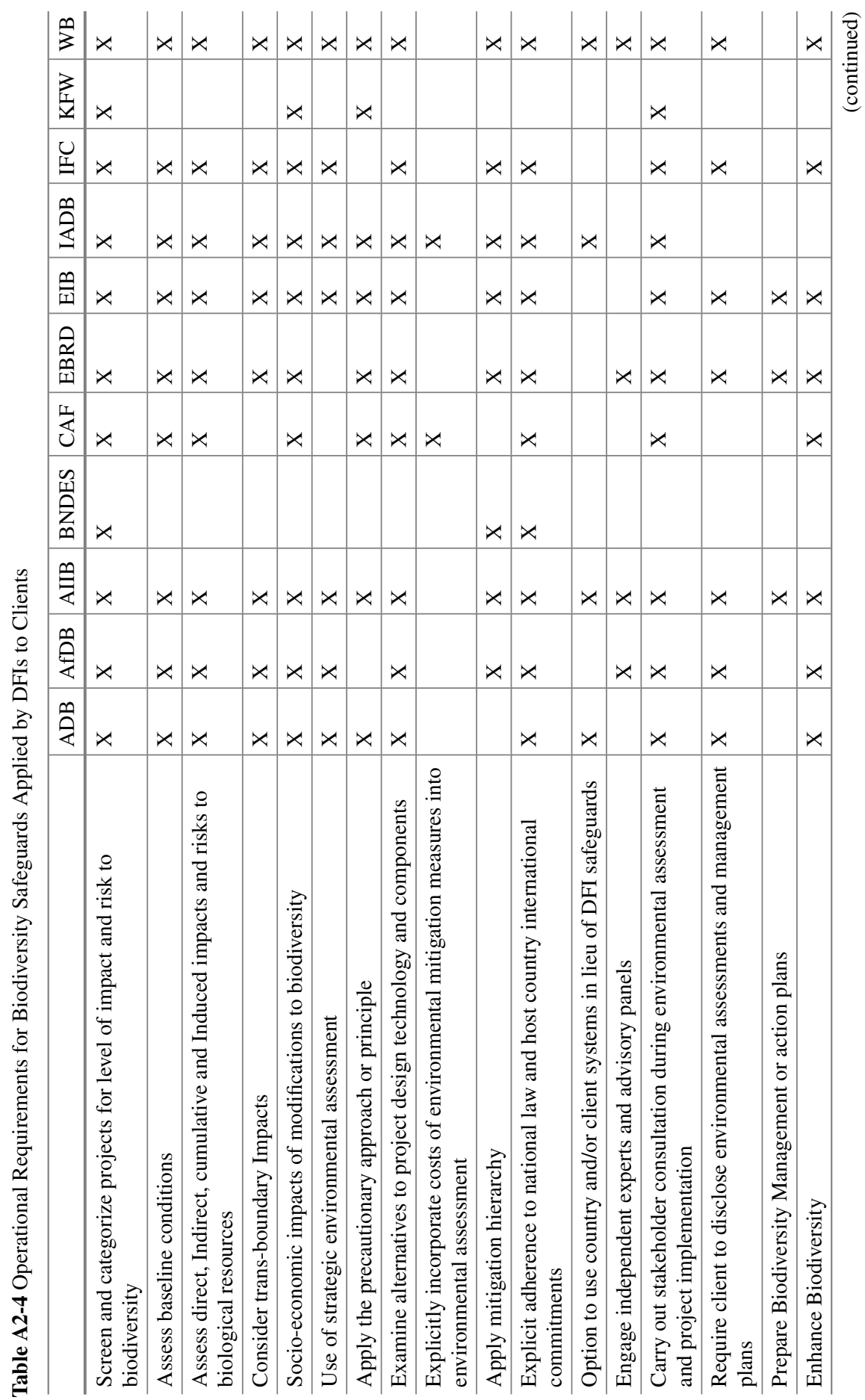


Annex 2: Supporting Evidence for Chapter 2

433

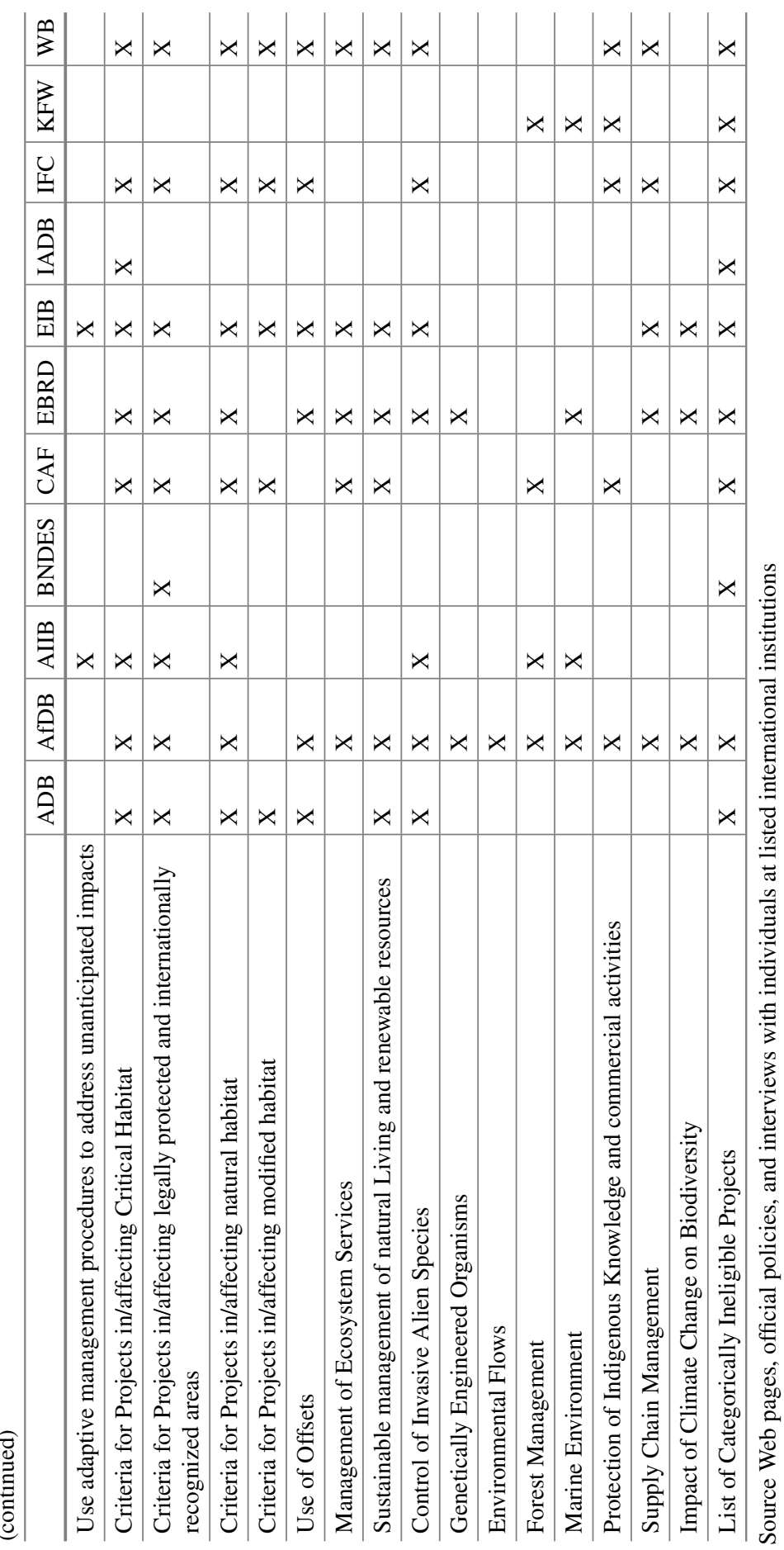




\section{Annex 3: Evidence from Chapter 3}

\section{Detailed descriptions of conservation finance initiatives in China}

Increasing transfer payments to ecological function areas. Since 2018 when the central government established the transfer payment system for key national ecological function areas, China has been intensifying the efforts to protect those areas. In 2018 , the state made a transfer payment of 72.1 billion yuan to key national ecological function areas, 9.4 billion more than it did the previous year, registering an increase of $15 \%$. Meanwhile, China has kept expanding the scope of key national ecological function areas. Once included in the scope, the area will receive financial and policy support as long as it strictly implements the negative list system for industrial access. According to relevant regulations, a region counted as a key national ecological function area needs to strengthen ecological protection and restoration, regulate the boundaries of industrialization and urbanization, and enhance the supply capacity of eco-products.

Strengthening fiscal support from the central government to forestry ecological protection. On July 27, 2018, the Ministry of Finance and the State Administration of Forestry and Grassland jointly issued the Management Measures for Forestry Ecological Protection and Recovery Funds, aiming at regulating the management of Forestry Ecological Protection and Recovery Funds, coordinating the integrated use of such funds, improving the efficiency of utilization and facilitating forestry ecological protection and recovery. According to the Measures, Forestry Ecological Protection and Recovery Funds refer to special transfer payment funds in the central budget for the social insurance and social expenditure of Natural Forest Protection Project (hereinafter referred to as "NFPP"), the cessation of commercial clear-cutting of natural forest, improving relevant policies on returning farmland to forestry and initiating a new round of returning farmland to forestry and grassland. In 2018, a total of 41.604 billion yuan was allocated to several provinces, of which Heilongjiang received the most, 8.595 billion. The Measures has clearly stated that the funds are allocated based on the factor method. The standard of cash subsidy for returning farmland to forestry is as follows: for the Yangtze River Basin and southern areas, 125 yuan per mu each year; for the Yellow River Basin and northern areas, 90 yuan per mu each year. Those returned eco-forests will be subsidized for 8 years, and those returned economic forests for 5 years. As for the new round of returning farmland to forestry and grassland, the returned forests will receive a cash subsidy of 1200 yuan per mu, paid at 3 intervals within 5 years, with 500 yuan in the first year, 300 yuan in the second year, and 400 in the third year; the returned grasslands will receive a cash subsidy of 850 yuan, paid at 2 intervals within 3 years, with 450 yuan in the first year and 400 yuan in the second.

Strengthen fiscal support from the central government to ecological protection and restoration of wetlands. From 2013 to 2016, the central government allocated 5 billion yuan to protect wetlands in China, and continued to provide support through 
the Funds for Reform and Development of Forestry afterwards. The measures taken include: First, supporting the protection and restoration of wetlands. For wetlands of international/national importance, national wetland parks at important ecological locations, and national wetland nature reserves at or above the provincial level managed by the forestry system, efforts will be made to protect and restore the wetlands, improve the current ecological status, and maintain the health of the local eco-system. Second, supporting returning farmland to wetland. It is encouraged to return farmlands to wetlands within the wetlands of international importance, national wetland nature reserves, and provincial nature reserves within wetlands of national importance managed by the forestry system, so as to expand the area of wetlands and improve the surrounding ecological status. Third, supporting the wetland ecological benefit compensation. For important wetlands on the route of migratory birds managed by the forestry system, their loss due to the protection of birds and other wild animals will be properly compensated. In so doing, all parties are motivated to protect wetlands and maintain the wetlands' ecosystem service functions.

Promote the grassland ecological protection subsidy incentive policy continuously. Since 2011 when the state implemented the grassland ecological protection subsidy incentive policy in 8 major pastoral areas in Inner Mongolia, Xinjiang, Tibet, Qinghai, Sichuan, Gansu, Ningxia and Yunnan and Xinjiang Production and Construction Corps, and gave out a total of 13.6 billion yuan as subsidies, 36 pastoral and agricultural pastoral regions in 5 non-major pastoral provinces including Heilongjiang have been added to the scope, altogether covering 268 pastoral and mixed farming-pastoral counties. In recent years, the state together with the General Bureau of Land Reclamation of Heilongjiang has implemented the grassland subsidy incentive in 13 provinces including Shanxi and Hebei and production and construction corps, achieving remarkable results in improving the grassland ecosystem, the production of animal husbandry and the life of herders. In 2018, a new round of grassland ecological protection subsidy incentive of 18.76 billion yuan was included in the central budget to support the banned grazing area of 1.206 billion mu and the grassanimal balance area of 2.605 billion mu, and award those regions with outstanding performance. The funds were utilized by local governments in grassland management and the transformation and upgrading of the production mode. Besides, the subsidies for banning grazing and incentive for grass-animal balance were required to be given out based on the principle of "to clear targets in a reasonable amount accurately", making sure each target could get their share in time. The distribution of the funds is publicized at the village-level, accepting surveillance by the masses. In addition to supporting the implementation of subsidies for banning grazing and incentives for grass-animal balance, the performance appraisal also requires no less than $70 \%$ of the funds should be used in protecting the grassland ecosystem and developing grass-based livestock husbandry, that relevant trails should be conducted in accordance with local realities, and that support to new agricultural operators should be enhanced concerning the development of modern grass-based livestock husbandry. 
Launching pilot programs on the unified confirmation and registration of natural resources. The confirmation and registration of natural resources is important to promoting the reform of the property right mechanism of natural resource assets, which, is a key part of China's ecological civilization construction. On July 6, 2018, an evaluation and acceptance meeting for the pilot programs concerning the unified confirmation and registration of natural resources was held in Beijing by seven ministries and commissions, including the Ministry of Natural Resources. At the meeting, pilot programs of several provinces, municipalities and autonomous regions passed the acceptance, indicating that much progress has been made in the field of confirmation and registration of natural resources after over one year's hard work. By the end of October in 2018, 1191 natural resource registration units have been established in 12 provinces and 32 pilot areas, and the total registered area has reached $186,727 \mathrm{~km} 2$. Besides, the state also focused on exploring the confirmation and registration of national parks, wetlands, water flows, proven reserves of mineral resources. On the basis of real estate registration, with the core mission being making a clear distinction between national ownership and collective ownership, between national ownership and governments at different levels assuming ownership, between different collective owners, and between different types of natural resources, and bearing in mind the goal of adopting a holistic approach to conserving our mountains, rivers, forests, farmlands, lakes and grasslands, local governments completed the work on investigating resource ownership, establishing registration units, confirming and registering, constructing databases, etc., resulting an effective set of workflow, technical methods and specifications. Starting from the end of 2018 , the confirmation and registration of natural resources in key areas has been implemented nationwide step by step. It is planned that within 5 years, the unified confirmation and registration of natural resources in nature reserves will completed, such as national and provincial key parks, natural reserves and various natural parks (scenic spots, wetland parks, natural heritage, geoparks, etc.). At the same time, the unified confirmation and registration of individual natural resources with complete ecological functions owned by the public will be conducted, such as major rivers and lakes, key wetlands, key national forests, important grasslands, etc.

\section{Annex 4: Evidence from Chapter 4}

\section{China's Policy Implementation for Biodiversity Conservation}

In regard of biodiversity conservation policies, we've already had relevant legislation, technological innovation and international mechanisms in China. A preliminary legal framework for biodiversity conservation has been established, and technological innovation and international collaboration are making continuous progress.

The most important elements include:

- The Constitution, which establishes the fundamental law of the state 
- National laws and regulations, including the Marine Environment Protection Law, Water Law, Water Pollution Prevention and Control Law, Water and Soil Conservation Law, Fishery Law, Forest Law, Grassland Law, Wild Animal Conservation Law, Regulations on Wild Plants Protection, Regulations on the Protection of Terrestrial Wild Animals, Regulations on the Protection of New Varieties of Plants, Regulations on Nature Reserves, and Regulations on the Administration of Scenic and Historic Area

- Nine provinces have established regulations, including Regulations on the Protection of Wetlands in Heilongjiang Province, Regulations on the Protection of Wetlands in Gansu Province, and Regulations on the Protection of Wetlands in Poyang Lake in Jiangxi Province

- International conventions, including the Convention on Biological Diversity, Convention on Wetlands of International Importance Especially as Waterfowl Habitat, Convention on International Trade in Endangered Species of Wild Fauna and Flora, Convention Concerning the Protection of the World Cultural and Natural Heritage, Declaration of the United Nations Conference on the Human Environment, and Rio Declaration on Environment and Development

- Judicial measures established through the Supreme People's Court of China, which has organized a division for environmental resources and issued guidelines for biodiversity-related cases.

- Government-sponsored survey, research, and monitoring of biodiversity, producing species catalogs such as the Flora of China, Fauna of China, Cryptogamia of China, China Red Data Book of Endangered Animals, and others.

- Public awareness campaigns, both domestically and internationally.

\section{Elements of China's Governance Framework for Conservation}

In China, we have the Constitution, the fundamental law of the state, the Environmental Protection Law of the People's Republic of China, the basis of the environmental law system, and a set of separate laws and administrative regulations on biodiversity conservation issued on the spirit of the above laws, such as the Marine Environment Protection Law, Water Law, Water Pollution Prevention and Control Law, Water and Soil Conservation Law, Fishery Law, Forest Law, Grassland Law, Wild Animal Conservation Law, Regulations on Wild Plants Protection, Regulations on the Protection of Terrestrial Wild Animals, Regulations on the Protection of New Varieties of Plants, Regulations on Nature Reserves, and Regulations on the Administration of Scenic and Historic Areas. Besides, we also have local regulations on biodiversity conservation, for instance, the Regulations on the Protection of Wild Aquatic Animals, the Aquatic Resources Breeding Protection Regulations, Law on the Exclusive Economic Zone and the Continental Shelf, and the Regulations on the Protection of Fishery Resources Breeding of Bohai. Administrative regulations on biodiversity conservation in wetlands include the Ramsar Convention, Convention on Biological Diversity, etc. 
In terms of local legislation, 9 provinces have established relevant regulations, including the Regulations on the Protection of Wetlands in Heilongjiang Province, Regulations on the Protection of Wetlands in Gansu Province, and Regulations on the Protection of Wetlands in Poyang Lake in Jiangxi Province. In addition, a series of administrative laws and regulations have been issued, including regulations on nature reserves, regulations on the protection of wild plants, regulations on the safety management of agricultural GMOs, regulations on the administration of the import and export of endangered wild flora and fauna, regulations on the protection of wild medicine resources, etc. Some provincial governments and relevant authorities in charge have also formulated corresponding rules and regulations.

China has joined several international conventions related to biodiversity conservation, including the Convention on Biological Diversity, Convention on Wetlands of International Importance Especially as Waterfowl Habitat, Convention on International Trade in Endangered Species of Wild Fauna and Flora, Convention Concerning the Protection of the World Cultural and Natural Heritage, Declaration of the United Nations Conference on the Human Environment, and Rio Declaration on Environment and Development. Laws concerning the management of introduced species include the Law on the Entry and Exit Animal and Plant Quarantine, Animal Epidemic Prevention Law, Marine Environment Protection Law, Regulations on the Prevention of Livestock Epidemics, etc. As for the emerging safety issues concerning GMOs, the State Council has issued theRegulations on Administration of Agricultural Genetically Modified Organisms Safety in 2001. The promulgation of those laws and regulations has efficiently supervised and promoted the conservation of biodiversity in China.

The Supreme People's Court of China has set up a division for environmental resources and issued guidelines on conducting specialized investigations and trials of biodiversity conservation-related cases, so as to guide courts at all levels to classify cases based on different basins or eco-function areas, unify judicial criteria, and improve the multiple-channel dispute settlement mechanism, thus laying a solid foundation for enhancing the juridical protection of environmental resources including biodiversity. Chinese courts give full play to the role of environmental public litigation, trying public interest litigation cases concerning wetlands, forestry, endangered plants, migratory birds in accordance with relevant laws. In the ancient Wucheng Town of Yongxiu County near Poyang Lake, the first biodiversity judicial protection base has been established. Adhering to modern judicial concepts such as strict law enforcement, safeguarding rights and interests, focusing on prevention and restoration and encouraging public participation, the base aims to make the best of judicial services in the process of advancing ecological civilization construction through circuit courts and legal publicity.

Basic surveys, scientific researches and monitoring of biodiversity have been conducted, and technological innovation has been applied to promote the sustainable development of biodiversity. Relevant departments have organized a series of national and regional surveys, researches and monitoring on species and established corresponding databases, and have published several species catalogues such as the Flora of China, Fauna of China, Cryptogamia of China, China Red Data Book of 
Endangered Animals, etc. China has also drawn on international advanced experience and carried out demonstration projects, strengthened researches on the evaluation and management system of biological genetic resources, and tried to build a mechanism to communicate relevant traditional knowledge and share benefits, thus coordinating the relationship among knowledge protection, expansion and utilization.

China has raised public awareness to participate, and strengthened international cooperation and exchanges. Publicity campaigns on biodiversity conservation in various forms have been launched, and education in this regard has also been enhanced in the campus. Public monitoring and reporting systems for biodiversity conservation have been established and improved. Partnerships on biodiversity conservation have been built in order to give full play to the role of non-governmental non-profit organizations and philanthropic organizations, and mobilize stakeholders both in and out of China to promote the sustainable use of biodiversity resources. Moreover, China always sticks to its commitment to those conventions, introduces advanced experience from abroad, and actively participates in formulating relevant international rules.

\section{Additional Major Institutions with Conservation Management Responsibilities in China}

The China Biodiversity Conservation and Green Development Foundation (CBCGDF) is a leading nationwide non-profit public foundation and a social legal entity dedicated to biodiversity conservation and green development. The mission of CBCGDF is to mobilize the whole society to care about biodiversity conservation and support the cause of green development, protect strategic resources of the state, promote sustainable economic and social development, promote the construction of ecological civilization and achieve harmony between man and nature, thus building a better home for mankind.

In 2010, the General Assembly of the United Nations declared 2011-2020 the United Nations Decade on Biodiversity. The State Council established the National Committee for 2010 International Year of Biodiversity, and held a meeting on which they passed the China Action Plan for 2010 International Year of Biodiversity and China National Biodiversity Conservation Strategy and Action Plan (2011-2030). In the June of 2011, the State Council decided to change the name of the Committee to "China National Committee for Biodiversity Conservation", and it will continue to coordinate the efforts to protect biodiversity and guide China's action plan for the UN Decade on Biodiversity.

In 1992, the Biodiversity Committee of the Chinese Academy of Sciences (BCCAS) was established to coordinate researches on biodiversity. Its responsibilities are as follows: to make biodiversity research policies of CAS; to make a long-term guideline and work plan for CAS's biodiversity researches; to review the rules and regulations on observation and experiments, organizational management mechanisms, 
and fund allocation plans; to inspect the utilization of funds and the performance of work; to review academic exchanges and training programs; to make plans for domestic and international collaborative researches. BC-CAS will strive to implement the sub-project of "Biodiversity Research and Information Management", an environmental technical assistance project with loans from the World Bank. So far, $30+$ databases have been established, 25 of which contain over 140,000 records that can be accessed via Internet.

\section{DFIs Governance Structures for Conservation}

- European Bank for Reconstruction and Development (EBRD): Borrowers are tasked with overseeing all management, monitoring, and reporting.

- International Finance Corporation (IFC): IFC works with private-sector borrowers, creating a triangular oversight relationship: IFC, client, and client's national government. Clients are generally tasked with monitoring and reporting, except for situations where national governments have domain over a natural resource or oversight responsibilities. In complex or high-risk scenarios, clients will be required to use the services of outside experts.

- Asian Infrastructure Investment Bank (AIIB) and Development Bank of Latin America (CAF): Borrowers are tasked with monitoring and reporting. The DFI may also carry out periodic site visits and works with implementers to mitigate any harm that has been caused.

- KfW agrees to a monitoring and reporting plan with the borrower or client, who is then empowered to manage that plan.

- Asian Development Bank (ADB): Borrowers compile regular reports, while the ADB maintains responsibility for due diligence in reviewing these reports. The ADB also carries out periodic site visits and works with implementers to mitigate any harm that have been caused.

- African Development Bank (AfDB): The AfDB will occasionally carry out independent audits of projects with substantial risks to biodiversity, including the use of third-party auditors. In cases where problems come to light, it designs action plans with measurable outcomes in conjunction with the borrower, with the aim of strengthening local capacity to monitor and manage projects and mitigate harm.

- Inter-American Development Bank (IADB) and World Bank (WB): These DFIs monitor compliance and oversee reporting. 
Table A4-1 Commonalities Among DFI Guidelines for Project-Level Grievance Mechanisms

\begin{tabular}{|c|c|c|c|c|c|c|c|c|}
\hline & AfDB & ADB & AIIB & EBRD & EIB & IFC & KfW & WB \\
\hline \multicolumn{9}{|l|}{ Institutional Location } \\
\hline $\begin{array}{l}\text { It should be independent and } \\
\text { monitored by a } 3^{\text {rd }} \text { party }\end{array}$ & $\mathrm{X}$ & & & & & & & \\
\hline $\begin{array}{l}\text { It may be internal or external, as } \\
\text { the DFI deems suitable }\end{array}$ & & & $\mathrm{X}$ & & & & & \\
\hline \multicolumn{9}{|l|}{ Resources } \\
\hline $\begin{array}{l}\text { It should be scaled to the risks and } \\
\text { impacts of the project }\end{array}$ & & $\mathrm{X}$ & $\mathrm{X}$ & $\mathrm{X}$ & $\mathrm{X}$ & $\mathrm{X}$ & $\mathrm{X}$ & $\mathrm{X}$ \\
\hline $\begin{array}{l}\text { It should be adequately budgeted } \\
\text { and staffed }\end{array}$ & & & & & $\mathrm{X}$ & & & \\
\hline \multicolumn{9}{|l|}{ Design and establishment } \\
\hline $\begin{array}{l}\text { It should be designed in } \\
\text { cooperation with the } \\
\text { borrower/client to ensure } \\
\text { legitimacy, accessibility, } \\
\text { predictability, and equitability }\end{array}$ & $\mathrm{X}$ & & & & & & & \\
\hline $\begin{array}{l}\text { It should be established as early as } \\
\text { possible in the project } \\
\text { development process }\end{array}$ & & & & $\mathrm{X}$ & & & & \\
\hline \multicolumn{9}{|l|}{ Process } \\
\hline $\begin{array}{l}\text { It should address affected people's } \\
\text { concerns promptly }\end{array}$ & $\mathrm{X}$ & $\mathrm{X}$ & & $\mathrm{X}$ & $\mathrm{X}$ & $\mathrm{X}$ & & \\
\hline $\begin{array}{l}\text { It should use a clear and } \\
\text { transparent process }\end{array}$ & & $\mathrm{X}$ & $\mathrm{X}$ & $\mathrm{X}$ & $\mathrm{X}$ & $\mathrm{X}$ & & \\
\hline $\begin{array}{l}\text { It should have a predictable } \\
\text { process }\end{array}$ & $\mathrm{X}$ & & & & $\mathrm{X}$ & & & \\
\hline $\begin{array}{l}\text { It should be gender responsive or } \\
\text { sensitive }\end{array}$ & & $\mathrm{X}$ & $\mathrm{X}$ & & & & & \\
\hline It should be culturally appropriate & & $\mathrm{X}$ & $\mathrm{X}$ & $\mathrm{X}$ & & $\mathrm{X}$ & $\mathrm{X}$ & \\
\hline $\begin{array}{l}\text { It should be free from } \\
\text { manipulation, coercion, or } \\
\text { interference }\end{array}$ & & & & $\mathrm{X}$ & & & & \\
\hline $\begin{array}{l}\text { It should have a publicly } \\
\text { accessible register of cases and } \\
\text { outcomes }\end{array}$ & $\mathrm{X}$ & & $\mathrm{X}$ & & & & & \\
\hline $\begin{array}{l}\text { It should report regularly to the } \\
\text { public on its implementation }\end{array}$ & & & & $\mathrm{X}$ & $\mathrm{X}$ & & & \\
\hline
\end{tabular}

(continued) 
(continued)

Table A4-1, continued: Commonalities Among DFI Guidelines for Project-Level Grievance Mechanisms

\begin{tabular}{|l|c|c|c|c|c|c|c|c|}
\hline & AfDB & ADB & AIIB & EBRD & EIB & IFC & KfW & WB \\
\hline $\begin{array}{l}\mid 7 \\
\text { Treatment of complainants } \\
\text { It should protect complainants } \\
\text { from intimidation/retaliation }\end{array}$ & & & $\mathrm{X}$ & $\mathrm{X}$ & & $\mathrm{X}$ & & \\
\hline $\begin{array}{l}\text { It should allow complainants to be } \\
\text { remain anonymous if requested }\end{array}$ & & & $\mathrm{X}$ & & $\mathrm{X}$ & & & \\
\hline $\begin{array}{l}\text { It should be free of cost to } \\
\text { stakeholders }\end{array}$ & $\mathrm{X}$ & & & & $\mathrm{X}$ & $\mathrm{X}$ & & \\
\hline $\begin{array}{l}\text { It should be readily accessible to } \\
\text { all segments of affected people }\end{array}$ & & $\mathrm{X}$ & $\mathrm{X}$ & & & & & \\
\hline $\begin{array}{l}\text { The client should inform } \\
\text { stakeholders of its availability }\end{array}$ & & & $\mathrm{X}$ & $\mathrm{X}$ & & $\mathrm{X}$ & & \\
\hline
\end{tabular}

Note: AfDB: African Development Bank; ADB: Asian Development Bank; AIIB: Asian Infrastructure Investment Bank; EBRD: European Bank for Reconstruction and

Development; EIB: European Investment Bank; IFC: International Finance Corporation; KfW: German development bank, originally Kreditanstalt für Wiederaufbau; WB: World Bank.

\section{References}

1. PETRI, P.A., PLUMMER, M.G.: The Economic Effects of the Trans-Pacific Partnership: New Estimates [R]. Washington, DC: Peterson Institute for International Economics, (2016).

2. Belt and Road Portal-YIDAIYILU.GOV.CN: Illustration: BRI six years report card [EB/OL]. https://www.yidaiyilu.gov.cn/xwzx/gnxw/102792.htm, (2019-09-09).

3. World Bank: Belt and Road Economics: Opportunities and Risks of Transport Corridors [R]. Washington, D.C: World Bank, (2019).

4. Ministry of Commerce of the people's Republic of China: "Belt and Road" economic and trade cooperation has achieved new development and new breakthrough [EB/OL]. http://www.mof com.gov.cn/article/ae/ai/202001/20200102928961.shtml, (2020-01-09).

5. BHATTACHARYA, A., GALlAGHER, K.P., MUÑOZ CABRÉ, M., JEONG, M., MA, X.: Aligning G20 Infrastructure Investment with Climate Goals and the 2030 Agenda [R]. Foundations 20 Platform, a report to the G20, (2019).

6. YOSHINO, N., ABIDHADJAEV, U.: Impact of Infrastructure Investment on Tax: Estimating Spillover Effects of the Kyushu High-Speed Rail Line in Japan on Regional Tax Revenue [R]. ADBI Working Papers 574, Asian Development Bank Institute, (2016).

7. DREHER, A., FUCHS, A., PARKS, B., STRANGE, A., TIERNEY, M.J.: Aid, China, and Growth: Evidence from a New Global Development Finance Dataset [R]. Williamsburg, VA: AidData at William \& Mary, (2017).

8. HUGHES, A.: Understanding and minimizing environmental impacts of the Belt and Road Initiative [J]. Conserv. Biol. 33(4), 883-894 (2019).

9. Liu et al.: Risks of Biological Invasion on the Belt and Road, Current Biology 29, 499-505, (2019).

10. LOSOS, E.C., PFAFF, A., OLANDER, L.P., MASON, S., MORGAN, S.: Reducing Environmental Risks from Belt and Road Initiative Investments in Transportation Infrastructure [R]. Washington, DC: World Bank Group, (2019). 
11. NARAIN, D., MARON, M., TEO, H.C., HUSSEY, K., LECHNER, A.M.: Best-Practice Biodiversity Safeguards for Belt and Road Initiative's Financiers [J]. Nat. Sustain. 3(8), 1-8 (2020).

12. COSTANZA, R., de GROOT, R., SUTTON, P., et al.: Changes in the global value of ecosystem services [J]. Global Environ. Chang. 26, 152-158 (2014).

13. DAMANIA, R., Desbureaux, S., Scandizzo, P.L., Mikou, M., Gohil, D., Said, M.: When Good Conservation Becomes Good Economics [R]. Washington, DC: World Bank, (2019).

14. Global Environment Facility: Mainstreaming Gender at the GEF [R]. Washington, DC: GEF, (2013).

15. ROCHELEAU, D.E.: Gender and Biodiversity: A Feminist Political Ecology Perspective [J]. IDS Bull-I. Dev. Stud. 26(1), 9-16 (1995).

16. XI J.: "Work Together to Build the Silk Road Economic Belt and The 21st Century Maritime Silk Road." Opening Ceremony Speech of the Belt and Road Forum for International Cooperation [J]. Quishi Journal 9(3), 32 (2017).

17. World Bank: Safeguards and Sustainability Policies in a Changing World [R]. Washington, DC: World Bank, Independent Evaluation Group, (2010).

18. China Development Bank and United Nations Development Program.: Harmonizing Investment and Financing Standards towards Sustainable Development along the Belt and Road, Beijing, UNDP. https:/www.cn.undp.org/content/china/en/home/library/south-south-cooper ation/harmonizing-investment-and-financing-standards-.html, (2019).

19. International Finance Corporation.: Good Practice Handbook: Land Acquisition and Resettlement. Washington, D.C.: IFC. https://www.ifc.org/wps/wcm/connect/74f457f6-ddf7-44ec87bb-fed991b978fc/Draft_Resettlement+Handbook_Disclosure_March132019_Final.pdf, (2019).

20. IRWIN, A., GALLAGHER, K.P.: Chinese Mining in Latin America: a Comparative Perspective [J]. Journal of Environment and Development 22(2), 207-234 (2013).

21. RAY, R., GALLAGHER, K.P., LOPEZ, A., SANBORN, C.: China in Latin America: Lessons for South South Cooperation for Sustainable Development [R]. Global Development Policy Center, Boston University, (2015).

22. Convention on Biological Diversity.: "Report of the Eighth Meeting of the Parties to the Convention on Biological Diversity." Curitiba, Brazil: Conference of the arties to the CBD. https:// www.cbd.int/doc/meetings/cop/cop-08/official/cop-08-31-en.pdf, (2006).

23. Global Environment Facility.: "GEF-7 Replenishment Programming Directions." Stockholm, Sweden: Fourth Meeting of the Seventh Replenishment of the GEF Trust Fund. https://www.thegef.org/sites/default/files/publications/GEF-7\%20Programming\%20D irections\%20-\%20GEF_R.7_19.pdf, April 25, 2018.

24. World Bank: Annual Report 2020: Ending Poverty, Investing in Opportunity [R]. Washington, DC: World Bank, (2020).

25. Equator Principles.: "The Equator Principles.” https://equator-principles.com/wp-content/upl oads/2020/05/The-Equator-Principles-July-2020-v2.pdf, (2020).

26. RAY, R., GALLAGHER, K.P., SANBORN, C.: Development Banks and Sustainability in the Andean Amazon [M]. London: Routledge, (2019).

27. Asian Infrastructure Investment Bank (AIIB): Environmental and Social Framework [EB/OL]. https://www.aiib.org/en/policies-strategies/framework-agreements/environmentalsocial-framework.html, (2019).

28. African Development Bank (AfDB) Integrated Safeguard System: Policy Statement and Operational Safeguards [R]. Tunis: African Development Bank Group, (2013).

29. World Bank: ESS6: Biodiversity Conservation and Sustainable Management of Living Natural Resources [R]. Washington DC: World Bank, (2018).

30. Development Bank of Latin America (CAF): Environmental and Social Safeguards for CAF/GEF Projects Manual [EB/OL]. https://www.caf.com/media/6742/d0-7_s_e_safeguards_ manual_to_caf-gef_projects_may_2015_28.pdf,(2015).

31. Convention on Biological Diversity: 2015-2020 Gender Action Plan [EB/OL]. https://www. cbd.int/gender/action-plan/, (2017-10-02). 
32. Climate Investment Funds: CIF Gender Action Plan - Phase 2 [EB/OL]. https://www.climat einvestmentfunds.org/sites/default/files/ctf_scf_decision_by_mail_cif_gender_action_plan_p hase_2_final_revised.pdf, (2016-11-22).

33. Green Climate Fund: Mainstreaming Gender in Green Climate Fund Projects [R]. Yeonsu-gu, South Korea: GCF, (2017).

34. International Finance Corporation: IFC Performance Standards [R]. Washington, DC: IFC, (2012).

35. KVAM, R.: Meaningful Stakeholder Engagement: A Joint Publication of the MFI Working Group on Environmental and Social Standards [R]. Washington, DC: Inter-American Development Bank, (2019).

36. MONTANARELLA, L., SCHOLES, R., BRAINICH, A.: The IPBES assessment report on land degradation and restoration [R]. Bonn, Germany: Intergovernmental Science-Policy Platform on Biodiversity and Ecosystem Services, (2018).

37. LIU, G.: Exploring the ecological compensation system with Chinese characteristics [N]. China Environment News. https://www.gmw.cn/xueshu/2019-12/17/content_33406914.htm, (2019_ 12-17).

38. DONG, Z., LI, H., GE, C., WANG, J., HAO, C., CHENG, C., LONG, F., LI, X.: Annual report on environmental and economic policy 2017 [J]. Environmental Economy 4, 12-35 (2018).

39. Dong Zhanfeng, Li Hongxiang, Ge Chazhong, Wang Jinnan, Hao Chunxu, Cheng Cuiyun, Long Feng, Li Xiaoliang.: "Environmental Economic Policy Annual Report 2017." Environmental Economics 4: 12-35 (2018).

40. Ministry of Finance.: "Rules of Transfer Payments from the Central Government to Local Key Ecological Function Areas." 86, 2018.6, (2018).

41. Chinese Academy of Environmental Planning.: "China Environmental Economic Policy Progress Annual report: 2017.” 2018.1, (2018).

42. The Nature Conservancy (TNC). China TNC cooperates with Zhejiang Longwu in water source protection project [EB/OL]. http://www.tnc.org.cn/\#News\#schedule\#iframe99dc279553caa33 1d70c9f0840779587b1f0c4fddb7a32175cd9319c7a817b5db938ef981a6ed605397fb1, (201501-15).

43. Wanxiang Turst. Innovate new business model, Wanxiang Trust launched the first water fund trust in China [EB/OL]. http://biz.zjol.com.cn/system/2015/11/18/020917870.shtml, (2015).

44. SCHOMERS, S., Matzdorf, B.: Payments for Ecosystem Services: A Review and Comparison of Developing and Industrialized Countries [J]. Ecosyst. Serv. 6, 16-30 (2013).

45. SALZMAN, JAMES., BENNETT, G., CARROLL, N., GOLDSTEIN, A., JENKINS, M.: The Global Status and Trends of Payments for Ecosystem Services [J]. Nat. Sustain. 1, 136-144 (2018).

46. Echavarría, Marta.: "Financing Watershed Conservation: The FONAG Water Fund in Quito Ecuador." In Selling Forest Ecosystem Services: Market-Based Mechanisms for Conservation and Development, Stefano Pagiola, Joshua Bishop, and Natasha Landell-Mills, Eds. London: Earthscan, (2002).

47. BULl, J.W., SUTTlE, K.B., GORDON, A., SINGH, N.J., MILNER-GULlAND, E.J.: Biodiversity Offsets in Theory and Practice [J]. Oryx 47(3), 369-380 (2013).

48. GELCICH, S., VARGAS, C., CARRERAS, M.J., CASTILLA, J.C., DONLAN, C.J.: Achieving Biodiversity Benefits with Offsets: Research Gaps, Challenges, and Needs [J]. Ambio 46, 184-189 (2017).

49. MCKENNEY, B.A., KIESECKER, J.M.: Policy Development for Biodiversity Offsets: A Review of Offset Frameworks [J]. Environ. Manage. 45, 165-176 (2010).

50. BULL, J.W., STRANGE, N.: The Global Extent of Biodiversity Offset Implementation under no Net Loss Policies [J]. Nat. Sustain. 1, 790-798 (2018).

51. GARDNER, T.A., VON HASE, A., BROWNLIE, S., et al.: Biodiversity Offsets and the Challenge of Achieving No Net Loss [J]. Conserv. Biol. 27(6), 1254-1264 (2013).

52. Villarroya, Ana, Ana Cristina Barros, and Joseph Kiesecker.: "Policy Development for Environmental Licensing and Biodiversity Offsets in Latin America.” PLOS ONE 9(9): e107144. https://doi.org/10.1371/journal.pone.0107144, (2014). 
53. BEZOMBES, L., GAUCHERAND, S., KERBIRIOU, C., REINART, M.E., SPIEGELBERGER, T.: Ecological Equivalence Assessment Methods: What Trade-Offs between Operationality, Scientific Basis and Comprehensiveness? [J]. Environ. Manage. 60, 216-230 (2017).

54. QUÉTIER, F., LAVOREL, S.: Assessing Ecological Equivalence in Biodiversity Offset Schemes: Key Issues and Solutions [J]. Biol. Conserv. 144(12), 2991-2999 (2011).

55. LUCK, G.W., CHAN, K.M.A., FAY, J.P.: Protecting ecosystem services and biodiversity in the world's watersheds [J]. Conserv. Lett. 2(4), 178-188 (2009).

56. BURIAN, G., SEALE, J., WARNKEN, M., et al.: Business Case for Investing in Soil Health [R]. Geneva: World Business Council for Sustainable Development, (2018).

57. CLARK, R., REED, J., SUNDERLAND, T.: Bridging funding gaps for climate and sustainable development: Pitfalls, progress and potential of private finance [J]. Land Use Policy 71, 335-346 (2018).

58. BASS, M.S., FINER, M., JENKINS, C.N., et al.: Global Conservation Significance of Ecuador's Yasuní National Park [J]. PLOS One 5(1), e8767 (2010).

59. Hoeksema, Bert W. "Delineation of the Indo-Malayan Centre of Maximum Marine Biodiversity: The Coral Triangle.” In Renema W. (eds) Biogeography, Time, and Place: Distributions,Barriers, and Islands. Topics In Geobiology, vol 29. Dordrecht: Springer. https://doi.org/ 10.1007/978-1-4020-6374-9_5, (2007).

60. KLINGER, J.M.: In Their Own Time, on Their Own Terms: Improving development bank project outcomes through community-centered sustainable development partnerships in the Brazilian Amazon [R]. Boston: University Global Development Policy Center, (2019).

61. DILLENBECK, M.: National Environmental Funds: A New Mechanism for Conservation Finance [J]. Parks 4(2), 39-46 (1994).

62. KNOX, J.H.: The Neglected Lessons of the NAFTA Environmental Regime [J]. Wake Forest Law Review 45, 391-424 (2010).

63. North American Development Bank.: North American Development Bank Annual Report [R]. San Antonio, TX: NADBank, (2019).

64. EHLER, C., DOUVERE, F.: Marine spatial planning: a step-by-step approach toward ecosystem-based management [R]. Paris: UNESCO, (2009).

65. Asian Development Bank (ADB).: Building Gender into Climate Finance: ADB Experience with Climate Investment Funds [R]. Manila: ADB, (2016).

Open Access This chapter is licensed under the terms of the Creative Commons AttributionNonCommercial-NoDerivatives 4.0 International License (http://creativecommons.org/licenses/bync-nd/4.0/), which permits any noncommercial use, sharing, distribution and reproduction in any medium or format, as long as you give appropriate credit to the original author(s) and the source, provide a link to the Creative Commons license and indicate if you modified the licensed material. You do not have permission under this license to share adapted material derived from this chapter or parts of it.

The images or other third party material in this chapter are included in the chapter's Creative Commons license, unless indicated otherwise in a credit line to the material. If material is not included in the chapter's Creative Commons license and your intended use is not permitted by statutory regulation or exceeds the permitted use, you will need to obtain permission directly from the copyright holder.

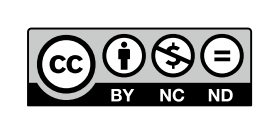

